\title{
Low Florida coral calcification rates in the Plio-Pleistocene
}

\author{
Thomas C. Brachert ${ }^{1}$, Markus Reuter ${ }^{2}$, Stefan Krüger ${ }^{1}$, James S. Klaus ${ }^{3}$, Kevin Helmle ${ }^{4}$, and Janice M. Lough ${ }^{5}$ \\ ${ }^{1}$ Institut für Geophysik und Geologie, Universität Leipzig, Leipzig, Germany \\ ${ }^{2}$ Institute of Earth Sciences, NAWI Graz Geocentre, University of Graz, Graz, Austria \\ ${ }^{3}$ Department of Geological Sciences, University of Miami, Coral Gables, Florida, USA \\ ${ }^{4}$ Oceanographic Center, Nova Southeastern University, Fort Lauderdale, Florida, USA \\ ${ }^{5}$ Australian Institute of Marine Science, Townsville MC, Australia \\ Correspondence to: T. C. Brachert (brachert@uni-leipzig.de)
}

Received: 6 November 2015 - Published in Biogeosciences Discuss.: 21 December 2015

Revised: 24 June 2016 - Accepted: 20 July 2016 - Published: 12 August 2016

\begin{abstract}
In geological outcrops and drill cores from reef frameworks, the skeletons of scleractinian corals are usually leached and more or less completely transformed into sparry calcite because the highly porous skeletons formed of metastable aragonite $\left(\mathrm{CaCO}_{3}\right)$ undergo rapid diagenetic alteration. Upon alteration, ghost structures of the distinct annual growth bands often allow for reconstructions of annual extension (= growth) rates, but information on skeletal density needed for reconstructions of calcification rates is invariably lost. This report presents the bulk density, extension rates and calcification rates of fossil reef corals which underwent minor diagenetic alteration only. The corals derive from unlithified shallow water carbonates of the Florida platform (south-eastern USA), which formed during four interglacial sea level highstands dated approximately 3.2, 2.9, 1.8 , and $1.2 \mathrm{Ma}$ in the mid-Pliocene to early Pleistocene. With regard to the preservation, the coral skeletons display smooth growth surfaces with minor volumes of marine aragonite cement within intra-skeletal porosity. Within the skeletal structures, voids are commonly present along centres of calcification which lack secondary cements. Mean extension rates were $0.44 \pm 0.19 \mathrm{~cm} \mathrm{yr}^{-1}$ (range 0.16 to $0.86 \mathrm{~cm} \mathrm{yr}^{-1}$ ), mean bulk density was $0.96 \pm 0.36 \mathrm{~g} \mathrm{~cm}^{-3}$ (range 0.55 to $1.83 \mathrm{~g} \mathrm{~cm}^{-3}$ ) and calcification rates ranged from 0.18 to $0.82 \mathrm{~g} \mathrm{~cm}^{-2} \mathrm{yr}^{-1}$ (mean $0.38 \pm 0.16 \mathrm{~g} \mathrm{~cm}^{-2} \mathrm{yr}^{-1}$ ), values which are $50 \%$ of modern shallow-water reef corals. To understand the possible mechanisms behind these low calcification rates, we compared the fossil calcification rates with those of modern zooxanthellate corals ( $z$ corals) from the Western Atlantic (WA) and Indo-Pacific calibrated against sea surface temperature (SST). In the fossil data, we found
\end{abstract}

a widely analogous relationship with SST in $z$ corals from the WA, i.e. density increases and extension rate decreases with increasing SST, but over a significantly larger temperature window during the Plio-Pleistocene. With regard to the environment of coral growth, stable isotope proxy data from the fossil corals and the overall structure of the ancient shallow marine communities are consistent with a well-mixed, open marine environment similar to the present-day Florida Reef Tract, but variably affected by intermittent upwelling. Upwelling along the platform may explain low rates of reef coral calcification and inorganic cementation, but is too localised to account also for low extension rates of Pliocene $z$ corals throughout the tropical WA region. Low aragonite saturation on a more global scale in response to rapid glacialinterglacial $\mathrm{CO}_{2}$ cyclicity is also a potential factor, but PlioPleistocene atmospheric $p \mathrm{CO}_{2}$ is generally believed to have been broadly similar to the present day. Heat stress related to globally high interglacial SST only episodically moderated by intermittent upwelling affecting the Florida platform seems to be another likely reason for low calcification rates. From these observations we suggest some present coral reef systems to be endangered from future ocean warming. 


\section{Introduction}

\subsection{Architecture of the zooxanthellate coral skeleton and systematics of skeletal calcification}

The skeleton of zooxanthellate corals ( $z$ corals) is a highly organised, porous hard tissue formed of mineral $\mathrm{CaCO}_{3}$ (aragonite). In X-ray images of slices parallel to the axes of the corallites (axes of maximum growth), massive $z$ coral skeletons typically display alternations of light and dark bands. One pair of these "density bands" usually represents 1 year of growth (Knutson et al., 1972) and forms the basis for the calibration of internal age models and for estimates of the extension rates, i.e. the rate of upward and outward growth of the colony surface (Lough and Cooper, 2011). Skeletal bulk density is a measure of the pore volumes within the skeleton; the less porosity, the closer the density will be to that of mineral aragonite $\left(2.93 \mathrm{~g} \mathrm{~cm}^{-3}\right)$. Extension rate and density combine for estimates of calcification rates according to Eq. (1) (Lough and Cooper, 2011):

calcification rate $\left(\mathrm{g} \mathrm{cm}^{-2} \mathrm{yr}^{-1}\right)=$ annual extension rate $\left(\mathrm{cm} \mathrm{yr}^{-1}\right) \times$ density $\left(\mathrm{g} \mathrm{cm}^{-3}\right)$.

Alternative concepts of quantifying coral skeletal growth have been reviewed by Pratchett an co-workers (Pratchett et al., 2015). In addition to the basic calcification parameters described above, serial chemical and isotope proxy data retrieved along the direction of maximum skeletal extension provide independent quantitative measures of the environment. Stable isotope ratios of the oxygen $\left(\delta^{18} \mathrm{O}\right)$ are sensitive to sea surface water temperature (SST) and serial samples over the growth bands allow for the documentation of seasonal or interannual SST variability on multiannual timescales (decade and century scale; Felis and Pätzold, 2004; Leder et al., 1996; Swart, 1983). Limitations of the method pertain to the influence of seawater $\delta^{18} \mathrm{O}$ which is subject to changes due to precipitation and/or evaporation (i.e. salinity), river discharge and global ice volume. To overcome the problem of variable seawater $\delta^{18} \mathrm{O}$ for SST estimates, chemical element proxies of SST rather insensitive to evaporation and/or precipitation $(\mathrm{Sr} / \mathrm{Ca}, \mathrm{U} / \mathrm{Ca}, \mathrm{Mg} / \mathrm{Ca})$ are in use in combination with skeletal $\delta^{18} \mathrm{O}$ (Felis et al., 2004; Shen and Dunbar, 1995; Swart, 1981). Other chemical elements $(\mathrm{Ba} / \mathrm{Ca}, \mathrm{Y} / \mathrm{Ca}, \mathrm{B} / \mathrm{Ca})$ and carbon stable isotope ratios $\left(\delta^{13} \mathrm{C}\right)$ have been shown to be recording sensitively productivity, river discharge, $\mathrm{pH}$, or also subtle diagenetic alterations (Allison et al., 2007; McCulloch et al., 2003; Sinclair et al., 1998; Swart et al., 2010).

In the geological record, the skeletons of scleractinian corals and other sedimentary grains composed originally of metastable aragonite $\left(\mathrm{CaCO}_{3}\right)$ usually form moldic porosity, or are more or less completely replaced by mosaics of blocky calcite spar (Schroeder and Purser, 1986). Although these secondary alterations generally pose no problem for classical approaches in palaeoecology and taxonomy, all information stored as isotope and geochemical proxy data have been reset and makes the corals no longer available as environmental or geochronological archives. The first diagenetic alterations of the skeletons still happen at the sea floor, in deeper parts of the skeleton where the living organic tissues were previously withdrawn. These alterations represent growths of inorganic aragonite fiber crystals and subtle dissolution phenomena within the centres of calcification (COC; Perrin, 2004). Differential diagenetic processes on crystalline phases and organic matrices also exist and include aragonite-aragonite recrystallisations associated with a loss of micron-sized growth information (McGregor and Gagan, 2003; Nothdurft and Webb, 2009; Perrin, 2004). In contrast, in the classical freshwater diagenetic environment, the primary surface area of the skeleton controls diagenetic susceptibility and rates of alteration (Constantz, 1986; Dullo, 1984). The freshwater effects are dominated by dissolution via moldic porosity and subsequent reduction of pore spaces by cementation, or dissolution and associated crystallisation of blocky calcite without developing a significant moldic stage (Bathurst, 1975). In the latter process, ghost structures reflecting original microstructures will be preserved (Flügel, 2004). More often, ghost structures of the growth bands form by subtle, diffusioncontrolled dissolution which preferentially starts at the COCs and continues to form increasingly hollow skeletal structures (Reuter et al., 2005). The rate of skeleton-internal dissolution via diffusion differs among growth bands within a specimen and responds to bands of higher and lower density (Reuter et al., 2005). Given the situation where no secondary addition of carbonate material has taken place, however, the hollow structures may still be suitable for isotope and geochemical proxy analysis (Mertz-Kraus et al., 2008, 2009a, b). Following infilling by late diagenetic calcite spar, this differential dissolution process leaves records of growth bands from which skeletal extension can be retrieved (Brachert et al., 2006b; Johnson and Pérez, 2006; Shinn, 1966). But, this process of dissolution and subsequent cementation of moldic and intra-particle porosity tends to destroy all information pertaining to skeletal density. Alteration of the primary skeleton along this diagenetic pathway is obvious by the presence of calcite, either replacing skeletal structures or infilling skeletal porosity. While the petrographic aspect of the calcite documents the type of freshwater or burial alteration environment, cathodoluminescence analysis and geochemical data may provide further information as to the redox character of the diagenetic fluids (Flügel, 2004). Alteration of aragonite is commonly a rapid process, but in the rare event of low porewater circulation rates, corals do escape diagenetic alteration (Anagnostou et al., 2011; Brachert et al., 2006a, 2016; Denniston et al., 2008a; Gothmann et al., 2015; Griffiths et al., 2013; Mertz-Kraus et al., 2008).

In this study we present calcification data from $z$ corals with rather intact primary skeletal density from PlioPleistocene interglacial deposits on the Florida Platform 


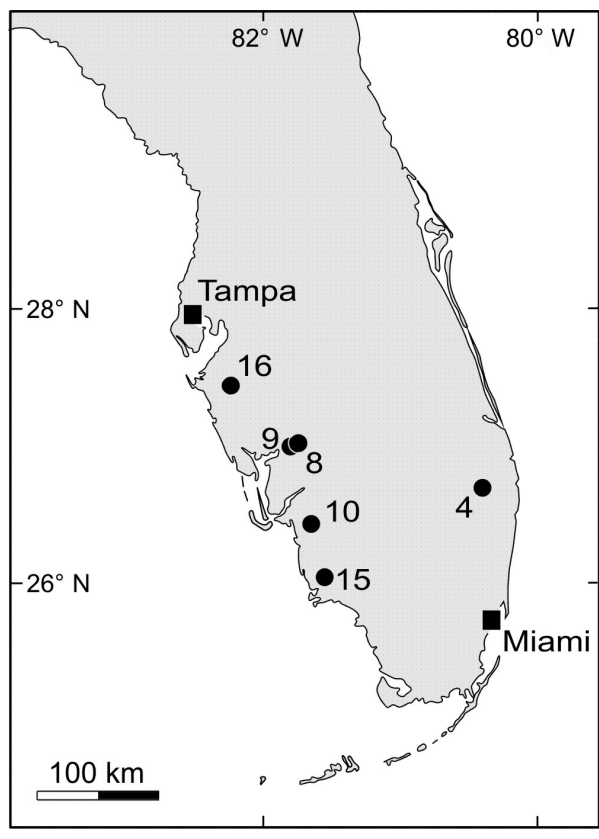

Figure 1. Sampling stations in southern Florida, USA (dots). See Table 1 for details and numbering of sampling stations.

(USA; Fig. 1). We show that corresponding calcification rates were $50 \%$ lower than they are in the present-day Western Atlantic (WA). For an understanding of the possible mechanisms behind these low calcification rates, we use modern analogue data compiled from the literature on recent $z$ corals of the WA and Indo-Pacific (IP). According to this database, temperature generally boosts calcification rates in modern $z$ corals, but field studies on single species of $z$ coral suggest the rates to decline beyond optimum values (Carricart-Ganivet et al., 2012; Cooper et al., 2008). The nonlinearity of calcification rates $\left(\mathrm{g} \mathrm{cm}^{-2} \mathrm{yr}^{-1}\right)$ derives from inputs of two independent variables: skeletal growth rate (extension rate, $\left.\mathrm{cm} \mathrm{yr}^{-1}\right)$ and skeletal density $\left(\mathrm{g} \mathrm{cm}^{-3}\right.$; Lough, 2008). The temperature effects on extension rates of Porites from the IP are well documented over a large temperature window and display slow increases with temperature below but sharp decreases above optimum (Cantin et al., 2010; Carricart-Ganivet et al., 2012; Lough and Barnes, 2000). The temperature responses of extension rate and density, however, are generally believed to markedly differ according to taxon and/or ocean region (Highsmith, 1979) and are further complicated by proximality trends reflecting temperature and seasonality gradients, exposure, effluxes of "inimical" bank waters, or nutrient supplies (Lough and Cooper, 2011; Manzello et al., 2015b). We discuss whether the patterns of $z$ coral calcification found in the fossils from the Florida Platform is a local or global signature corresponding with temperature stress or low supersaturation of the sea water with respect to aragonite $\left(\Omega_{\text {aragonite }}\right)$ during the PlioPleistocene interglacials. This study complements two previ- ous papers using sclerochronology of bivalves and $z$ corals for reconstructions of the paleoenvironments and long-term changes of seasonality in southern Florida (Brachert et al., 2014,2016 ) and provides a discussion of the quantitative data in the context of recent global $z$ coral calcification patterns.

\subsection{The Florida Platform during the Plio-Pleistocene interglacials}

During the Plio-Pleistocene interglacials, global sea levels were up to $22 \mathrm{~m}$ (Miller et al., 2012) or even $35 \mathrm{~m}$ higher (Dowsett and Cronin, 1990) and global mean temperatures 2 to $4{ }^{\circ} \mathrm{C}$ warmer than present, whereas SSTs of the warm pools at low latitudes were $\sim 2{ }^{\circ} \mathrm{C}$ higher than present $(\mathrm{Fe}$ dorov et al., 2013; O’Brien et al., 2014). Although dramatic cooling occurred in the high latitudes, long-term atmospheric $p \mathrm{CO}_{2}$ appears to have remained rather constant after the mid-Pliocene climatic optimum $(\sim 3 \mathrm{Ma})$ until the present (Seki et al., 2010). During and before the optimum, however, $p \mathrm{CO}_{2}$ reached values expected for the end of this century through the burning of fossil fuels (IPCC, 2013; Seki et al., 2010). Modelling of the oceanic carbonate systems suggest the long-term $p \mathrm{CO}_{2}$ changes to have had no effect on the saturation state of seawater with regard to $\Omega_{\text {aragonite }}$ (Hönisch et al., 2012), but evidence exists that rates of microbial carbonate precipitation and skeletal accretion of planktic foraminifera differed over the last glacial-interglacial cycle (Barker, 1986; Beaufort et al., 2011; Riding et al., 2014).

The Plio-Pleistocene Florida carbonate platform represents a stack of shallow marine carbonate sequences formed during sea level highstands which are separated by paleosols or thin freshwater units formed during lowstands. A pronounced reef system existed along the south-western margin of the peninsula (Meeder, 1979). The single unlithified marine units contain a diverse mollusk and coral fauna comparable to that of the present reef tracts and back-reef systems (Meeder, 1979; Petuch and Roberts, 2007). Combined oxygen and carbon stable isotope data $\left(\delta^{18} \mathrm{O}, \delta^{13} \mathrm{C}\right)$ of diagenetically pristine mollusks and $z$ corals from the platform sediments reflect the complexity of the depositional setting including brackish to hypersaline and well-mixed, open marine environments (Brachert et al., 2014; Lloyd, 1969; Tao and Grossman, 2010). The reasons for high benthic carbonate productivity by mollusks during the Plio-Pleistocene is controversial, and has been suggested to be due to high nutrient concentrations resulting from freshwater input (Tao and Grossman, 2010) or upwelling (Allmon, 2001; Allmon et al., 1995; Brachert et al., 2016; Emslie and Morgan, 1994; Jones and Allmon, 1995). Recently, SST estimates for the Pliocene and Pleistocene interglacial units have been retrieved from $\delta^{18} \mathrm{O}$ values from the reef corals Solenastrea and Orbicella and assuming a modern seawater value for $\delta^{18} \mathrm{O}\left(\delta^{18} \mathrm{O}_{\text {water }}\right)$ at the Florida Reef Tract (FRT). Apart from assumptions for $\delta^{18} \mathrm{O}_{\text {water }}$ low SSTs are believed to be essentially the effect of upwelling. The large range of SST values is also likely in part 
an artifact of the uniform value used for the calculations, irrespective of sampling locality and stratigraphic unit (Brachert et al., 2016). In contrast, seasonal SST variability $\left(\sim 7^{\circ} \mathrm{C}\right)$ inferred from cyclic $\delta^{18} \mathrm{O}$ variations of the fossils is more independent of assumptions of $\delta^{18} \mathrm{O}_{\text {water }}$. Reconstructed seasonality is not only remarkably constant within specimens and over the last 3.2 Ma, but also fits modern surface seasonality along the reef tract (Brachert et al., 2014, 2016). Large seasonality as prevailing off North Carolina (Macintyre and Pilkey, 1969) or in inner coastal waters of Florida Bay (FB; Swart et al., 1996) has not been encountered in the data from the reef corals and has also been taken for inferring a normal shallow-marine environment without unusual stress from cool waters or evaporation and freshwater influxes (Brachert et al., 2014).

In southern Florida, the most extensive growth of reef corals occurs at present along the FRT on the Atlantic side of the peninsula, whereas only limited $z$ coral growth occurs along the Gulf side in the west and the shallow FB in the south-east. On the Atlantic side, coral communities are characterized by diverse stands comprising abundant $\mathrm{Orbi}$ cella (Lidz, 2011), whereas on the Gulf side and in FB, coral growth is restricted to the two eurytopic taxa Siderastrea and Solenastrea (Okazaki et al., 2013; Swart et al., 1999). Published extension rates for recent Solenastrea inhabiting the most marine segments of FB range from 0.51 to $0.9 \mathrm{~cm} \mathrm{yr}^{-1}$ (Hudson et al., 1989; Swart et al., 1996). Recent Solenastrea has also been recorded to grow under rather cold water conditions along the US south-eastern Atlantic coast off North Carolina (Macintyre and Pilkey, 1969), but quantitative calcification data from that setting are not available, leaving the question unanswered regarding the effects of low SST on extension and density. Colony sizes at the northern sites similar to those of the lower latitudes have been suggested to indicate similar extension and calcification rates, however (Macintyre and Pilkey, 1969).

\subsection{Materials}

$Z$ corals were sampled from four distinct stratigraphic units of the Florida carbonate platform (USA) representing interglacial highstands of sea level subsequent to the Pliocene warm period. They were dated 3.2, 2.9, 1.8 and 1.2 million years (Ma) of the mid-Pliocene and early Pleistocene (Fig. 1, Table 1; Brachert et al., 2014). Our own sampling focused on Solenastrea $(n=11)$ which is a common taxon in the Plio-Pleistocene shallow water carbonates of southwestern Florida. This data set was complemented by specimens of Orbicella $(n=2)$ and Porites $(n=1)$ and one data set of a Solenastrea taken from the literature comprising serial $\delta^{18} \mathrm{O}$ and $\delta^{13} \mathrm{C}$ values and annual extension rates (Roulier and Quinn, 1995; Table 1).

\subsection{Methods}

Fossil corals selected for this study were cut into $<1 \mathrm{~cm}$ thick slabs along the plane of maximum growth using a conventional rock saw equipped with a water-cooled diamond blade. All corals were screened for diagenetic alteration using a binocular microscope and scanning electron microscope (SEM). In order to detect minimal contaminations by secondary calcite, powder samples taken at random were prepared for X-ray diffraction (XRD) and analysed using a Rigaku Miniflex diffractometer at angles between 20 to $60^{\circ} 2 \theta$. Only skeletal areas that retained their original aragonite mineralogy (XRD), skeletal porosity and microstructure without evidence for significant secondary crystal growth or dissolution (microscopic and SEM observation) were accepted for further sample preparation. Coral slabs of equal thickness were X-rayed using a digital X-ray cabinet (SHR $50 \mathrm{~V}$ ) to identify potential zones of diagenetic alteration (McGregor and Gagan, 2003; Reuter et al., 2005), bioerosion, and to document the density bands (Knutson et al., 1972). One coral specimen (452K1) was analysed geochemically using LA-ICP-MS (Böcker, 2014) with regard to concentrations of environmentally sensitive elements (e.g. $\mathrm{Sr} / \mathrm{Ca}$, $\mathrm{U} / \mathrm{Ca}, \mathrm{B} / \mathrm{Ca}$ ) and following recommendations for evaluating the diagenetic status of corals from strongly lithified and altered limestone (Anagnostou et al., 2011; Gothmann et al., 2015). LA-ICP-MS analyses were performed at the Max Planck Institut für Chemie (Mainz, Germany) using a NewWave UP 213 laser ablation system coupled to a ThermoFisher Element 2 ICP-MS.

Quantitative density measurements were made using the software CoralXDS (freeware) according to Helmle and co-workers (Helmle et al., 2002). In this approach, the CoralXDS software compares the gray values recorded in $\mathrm{X}$-radiographs from corals with those from aluminum plates having the same thickness as a background picture and an aluminum wedge for density calculations. Measurements were done along transects parallel to the corallites and parallel to the sampling transects for stable isotope analyses (Brachert et al., 2016). Bulk skeletal density was calculated as the mean of all individual measurements taken along a given transect. Calibration of the measurements was tested by measurements of standards for zero density (air) and massive aragonite (slice of a Glycimeris bivalve shell having a thickness equaling that of the coral slice). External analytical precision of the routine measurements was tested by double blind measurements, and mean deviation from regression $\left(R^{2}=0.91, p<0.05\right)$ was found to be $0.04 \pm 0.01 \mathrm{~g} \mathrm{~cm}^{-3}$ (range $=0.02$ to $0.05 \mathrm{~g} \mathrm{~cm}^{-3} ; n=18$ ).

As a baseline for the description and interpretation of the data from the fossils, we use calcification data from recent corals reported in the literature deriving equally from tropical and high latitudinal localities within the shallow-water reef belt (Baker and Weber, 1975; Bessat and Buigues, 2001; Carricart-Ganivet et al., 2000; Carricart-Ganivet and Merino, 

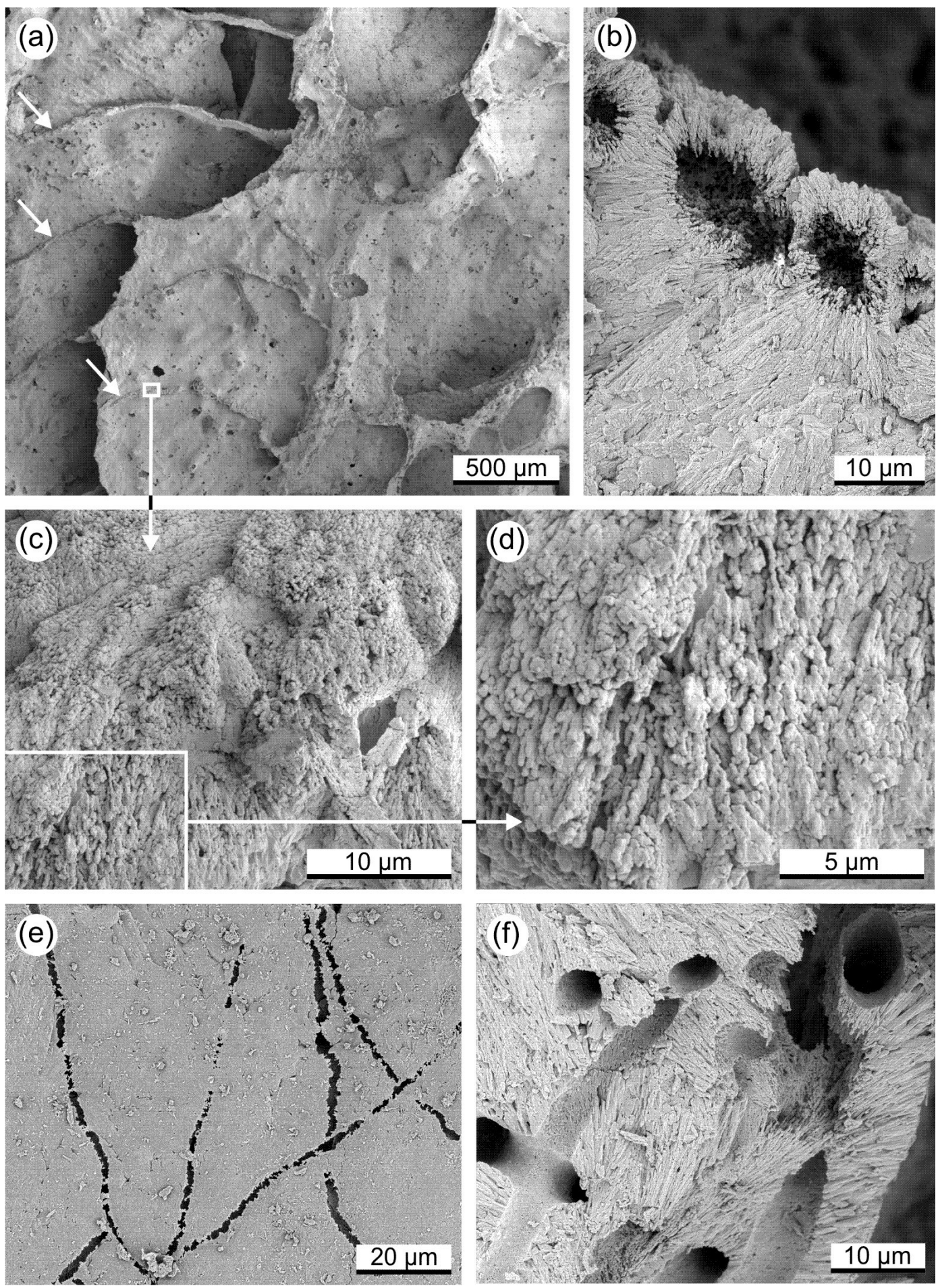

Figure 2. SEM images of fossil coral skeletons (Solenastrea sp.). (a) Overview of septal surfaces. Curved ridges represent the traces of dismantled dissepiments (arrows). (b) Cross-section of the skeleton showing the radial arrangement of aragonite fibers. Note holes at the centres of the trabecular fans which likely reflects preferential dissolution. (c) and (d) cross-section of a dissepiment composed of fans of fibers pointing downward. The individual fibers have distinct rounded edges and rounded tips. (e) Primary surface of the skeleton infested by microborings. (f) Cross-section of the skeleton showing radial fiber crystals and numerous microborings. The microborings are not constricted by cement or overgrowths. Note: white rectangles and vertical and/or horizontal arrows show the position of close-ups. Sample provenance: (a)-(d) Solenastrea sp. (EP 6), Caloosahatchee Fm., Brantley Pit, Florida, USA; (e) Solenastrea sp. (EP 5), Tamiami Fm. (Golden Gate Mb.), Mule Pen quarry; (f) Solenastrea sp. (EP 9C), Bermont Fm., Palm Beach Aggregates quarry, Florida, USA. 
Table 1. Sampling sites in southern Florida. The numbering follows that given by Brachert et al. (2014).

\begin{tabular}{|c|c|c|c|c|c|c|}
\hline No. & Site & Sample ID & Genus & GPS coordinates & Lithostratigraphy & $\begin{array}{l}\text { Age } \\
(\mathrm{Ma})\end{array}$ \\
\hline 4 & $\begin{array}{l}\text { Palm Beach } \\
\text { Aggregates }\end{array}$ & $\begin{array}{l}\text { EP8 } \\
\text { EP9A } \\
\text { EP9B } \\
\text { EP9C } \\
\text { EP9D }\end{array}$ & $\begin{array}{l}\text { Solenastrea } \\
\text { Solenastrea } \\
\text { Orbicella } \\
\text { Solenastrea } \\
\text { Solenastrea }\end{array}$ & $\begin{array}{l}26^{\circ} 41^{\prime} 44.5^{\prime \prime} \mathrm{N} \\
80^{\circ} 21^{\prime} 16.2^{\prime \prime} \mathrm{W}\end{array}$ & $\begin{array}{l}\text { Bermont Fm. } \\
\text { (Holey Land Mb.) }\end{array}$ & 1.2 \\
\hline 8 & $\begin{array}{l}\text { Brantley Pit, } \\
\text { Arcadia }\end{array}$ & EP6-S2 & Solenastrea & $\begin{array}{l}27^{\circ} 02^{\prime} 59.3^{\prime \prime} \mathrm{N} \\
81^{\circ} 49^{\prime} 36.7^{\prime \prime} \mathrm{W}\end{array}$ & $\begin{array}{l}\text { Caloosahatchee Fm. } \\
\text { (Bee Branch Mb.) }\end{array}$ & 1.8 \\
\hline 9 & $\begin{array}{l}\text { DeSoto Sand } \\
\text { and Shell LLC } \\
\text { (site 452) }\end{array}$ & $\begin{array}{l}452-\mathrm{K} 1-\mathrm{S} 6^{1} \\
452-\mathrm{K} 3^{1} \\
452-\mathrm{K} 4 \\
452-\mathrm{K} 5^{1} \\
452-13^{1} \\
452-\mathrm{K} 14 \\
452-\mathrm{K} 15^{1} \\
452-\mathrm{K} 17^{1}\end{array}$ & $\begin{array}{l}\text { Solenastrea } \\
\text { Solenastrea } \\
\text { Solenastrea } \\
\text { Solenastrea } \\
\text { Solenastrea } \\
\text { Solenastrea } \\
\text { Solenastrea } \\
\text { Solenastrea } \\
\text { Solenastrea } \\
\text { Solenastrea }\end{array}$ & $\begin{array}{l}27^{\circ} 03^{\prime} 35.2^{\prime \prime} \mathrm{N} \\
81^{\circ} 47^{\prime} 37.6^{\prime \prime} \mathrm{W}\end{array}$ & $\begin{array}{l}\text { Caloosahatchee Fm. } \\
\text { (Bee Branch Mb.) }\end{array}$ & 1.8 \\
\hline 15 & $\begin{array}{l}\text { Mule Pen } \\
\text { Quarry }\end{array}$ & $\begin{array}{l}\text { EP1-S2 } \\
\text { EP2-S2 } \\
\text { EP3 } \\
\text { EP5-S2 }\end{array}$ & $\begin{array}{l}\text { Solenastrea } \\
\text { Orbicella } \\
\text { Porites } \\
\text { Solenastrea }\end{array}$ & $\begin{array}{l}26^{\circ} 16^{\prime} 31.93^{\prime \prime} \mathrm{N}, \\
81^{\circ} 39^{\prime} 55.282^{\prime \prime} \mathrm{W}\end{array}$ & $\begin{array}{l}\text { Tamiami Fm. } \\
\text { (Golden Gate Mb.) }\end{array}$ & 2.9 \\
\hline 16 & $\begin{array}{l}\text { Quality } \\
\text { Aggregates } \\
\text { (APAC) }\end{array}$ & Coral \# $1^{2}$ & Solenastrea & Not available. & $\begin{array}{l}\text { Tamiami Fm. } \\
\text { (Pinecrest Mb., } \\
\text { unit 7) }\end{array}$ & 3.2 \\
\hline
\end{tabular}

${ }^{1}$ From Böcker (2014). ${ }^{2}$ From Roulier and Quinn (1995).

2001; Dodge and Brass, 1984; Dustan, 1975; ElizaldeRendon et al., 2010; Fabricius et al., 2011; Goodkin et al., 2011; Graus and Macintyre, 1982; Helmle et al., 2011; Highsmith et al., 1983; Hudson et al., 1989; Lough, 2008; Mallela and Perry, 2007; Tanzil et al., 2009), and one unpublished record of Solenastrea from FB (FB-6). We present a set of three descriptive diagrams for a comparison of the patterns of calcification (extension rate, bulk density, calcification rate) in the modern and fossil $z$ corals on the basis of linear regression. For a deeper understanding of the processes, we further apply quadratic polynomial regression models of experimental data calibrated with SST to account for the established non-linearity of life processes.

Stable isotope data described here are the same as reported in companion publications by Brachert et al. $(2014,2016)$ where all details of the methodology of sampling and analytical procedures have been reported in detail. All carbonate values are given in per mil (\%) relative to PDB according to the delta notation.

The scleractinian genus name Orbicella is used for corals previously assigned to Montastraea according to the revised taxonomic classification of the reef coral family Mussidae by Budd et al. (2012). According to the same work (op. cit.), the genus Diploria has been split into the genera Diploria and Pseudodiploria. We use the two genus names in combination as Diploria/Pseudodiploria, because our database likely incorporates material from both genera sensu (Budd et al. 2012).

Statistical analyses were performed using the PAST palaeontological statistics software package (version 3.01) for education and data analysis (freeware folk.uio.no/ohammer/past/). Variability of stable isotope data $\left(\delta^{18} \mathrm{O}, \delta^{13} \mathrm{C}\right)$ was evaluated using the $t$ test. A linear bivariate model was tested as to whether there were no statistical differences in the stable isotope values in a data set $(p>0.05)$ against the alternate hypothesis that there were significant differences $(p<0.05)$. Equality of regression slopes was tested using the $f$ test as assumed by analyses of covariance (ANCOVA). One-way analysis of variance (ANOVA) tested if there were no statistical differences in the mean growth parameters (extension, density, calcification) between two given coral sites $(p>0.05)$ against the alternate hypothesis that there were significant differences $(p<0.05)$. 


\section{Results and discussion}

\subsection{Preservation}

Visual inspection of the skeletons using a binocular microscope $(\times 15$ enlargement) and SEM revealed clean skeletal surfaces not covered systematically by secondary cements (Fig. 2a, e), except for localised, micron-scaled patches of spherulitic aragonite or patches of isopachous aragonite (Böcker, 2014). SEM observation has not revealed any clear evidence for aragonite-aragonite recrystallisations (Fig. 2) but some porosity within the centres of calcification (COCs, Fig. 2b). The latter does indeed imply some dissolution has occurred, and therefore, subtle reductions of skeletal density, however, since dissolution at the COCs has also been reported from recent specimens (Perrin, 2004), this effect may also be present in the data from recent corals.

Secondary calcite is not documented by XRD analysis (detection limit of the method $\sim 1 \%$ ) and has very rarely been observed to occur within skeletal growth porosity but never within voids formed by preferential dissolution of the COCs (Fig. 2b) or microborings (Fig. 2e, f). Published geochemical screenings using LA-ICP-MS for specimen $452 \mathrm{~K} 1$ (Böcker, 2014) documented variable ratios of $\mathrm{Sr} / \mathrm{Ca}$ and $\mathrm{U} / \mathrm{Ca}$ which are in phase with serial $\delta^{18} \mathrm{O}$ data. These element ratios reflect SST variations consistent with reconstructions on the basis of serial $\delta^{18} \mathrm{O}$ values and recent instrumental seasonality along the FRT (Böcker, 2014). The positive correlation of the $\mathrm{Sr} / \mathrm{Ca}$ with $\mathrm{U} / \mathrm{Ca}$ and the $\mathrm{B} / \mathrm{Ca}$ ratios fluctuating between 0.3 and $0.6 \mathrm{mmol} \mathrm{mol}^{-1}$ is fully consistent with modern $z$ corals and implies little alteration has taken place, especially because boron is known to be a diagenetically highly volatile element (Allison et al., 2010; Böcker, 2014). According to our conviction, all these data provide no critical evidence for the alteration of the original skeleton. Because of this line of reasoning and low overall calcite content evident from XRD analysis (calcite below detection limits), we refrained from measuring element ratios sensitive to the redox conditions of calcite precipitating freshwaters or burial fluids ( $\mathrm{Fe} / \mathrm{Ca}, \mathrm{Mn} / \mathrm{Ca}$ ) and other more sophisticated geochemical methods as potential measures of alteration (Anagnostou et al., 2011; Gothmann et al., 2015).

$\mathrm{X}$-radiographs display very regular expressions of density bands, concordant with the growth structures of the skeleton and stable isotope records, but no cloudy density variations or patches of high (low) density as documented from diagenetically altered specimens (Böcker, 2014; Brachert et al., 2006a; Mertz-Kraus, 2009). The presence of concordant density bands implies the preservation of original density variations of the skeleton and, therefore, supports the conclusion of a pristine state of preservation for the specimens under consideration (Fig. 3). It should be noted that density was measured using X-ray densitometry along transects defined from visual inspection of radiographs, and measurements were taken only in segments of the skeleton not af-
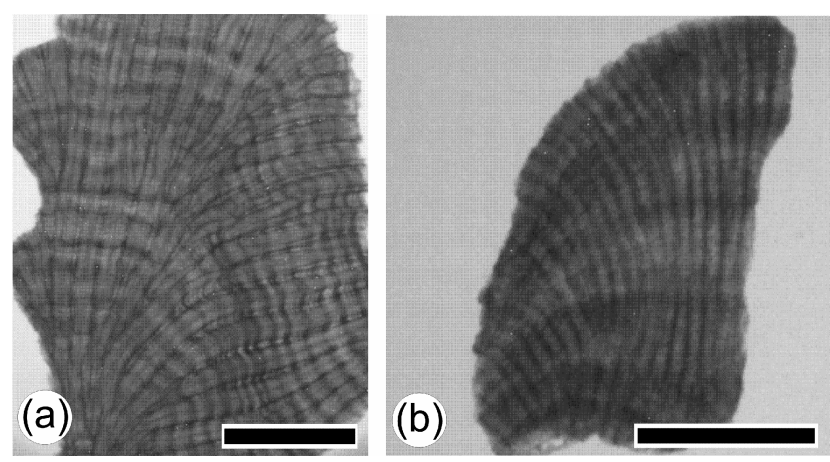

Figure 3. Digital X-ray photographs (positive prints) from fossil $z$ corals. (a) Solenastrea sp. (EP 5, Mule Pen Quarry, Tamiami Fm., age 2.5 Ma). (b) Porites sp. (EP3, Mule Pen Quarry, Tamiami Fm., age $2.9 \mathrm{Ma}$ ). Scale bar $2 \mathrm{~cm}$.

fected by borings (bivalves, sponges, sipunculids) or embedded encrusting biota (serpulids, bivalves). Bulk density data presented by this study and in a companion publication (Brachert et al., 2016) are, therefore, not influenced by the volume of macroscopic biogenic borings or incrustations, although these effects may also be inherent to published density data of recent corals. This is an important issue, because other approaches have used "net density" (i.e. the integrative weight of carbonate laid down by the coral and encrusting biota minus losses by bioerosion within a volume) for comparative calcification studies (Kuffner et al., 2013). In contrast to density, extension rate is not sensitive to diagenetic alterations and many data have been retrieved earlier from highly altered fossil coral specimens of Neogene age (Brachert et al., 2006b; Gischler et al., 2009; Johnson and Pérez, 2006; Reuter et al., 2005). All of these observations and reasoning suggest the $z$ corals selected for this calcification study to be essentially unaltered by diagenesis.

\subsection{Calcification}

The Pliocene and Pleistocene $z$ corals from the Florida Platform display extension rates that range from 0.16 to $0.86 \mathrm{~cm} \mathrm{yr}^{-1}$ with a mean value of $0.44 \pm 0.19 \mathrm{~cm} \mathrm{yr}^{-1}$ $(n=15, \pm 1 \sigma)$, bulk skeletal densities between 0.55 and $1.52 \mathrm{~g} \mathrm{~cm}^{-3}$ with a mean of $0.86 \pm 0.22 \mathrm{~g} \mathrm{~cm}^{-3}(n=14)$, and skeletal calcification rates from 0.18 to $0.54 \mathrm{~g} \mathrm{~cm}^{-2} \mathrm{yr}^{-1}$ with a mean of $0.34 \pm 0.11 \mathrm{~g} \mathrm{~cm}^{-2} \mathrm{yr}^{-1}(n=14$; Fig. 4, Table 3). Annual extension rates and bulk skeletal density show a significant negative correlation $\left(R^{2}=0.329 ; p=0.026\right)$, i.e. density decreases with increasing extension rates. In contrast, extension rates and calcification rates display a positive relationship $\left(R^{2}=0.484 ; p=0.004\right)$, which implies that calcification rates also decline with increasing extension. Lastly, bulk density and calcification rate display no relationship $\left(R^{2}=0.025 ; p=0.797 ;\right.$ Fig. 4$)$. Although no statistics were applied to the data of Orbicella $(n=2)$ and Porites $(n=1)$ their calcification systematics seem to be indistinguishable 
Table 2. Extension rate, bulk density and calcification rate in recent and fossil reef corals. Bold: minimum values. Data sets listing only extension rates not included in this table.

\begin{tabular}{|c|c|c|c|c|c|c|c|c|c|c|}
\hline Taxon & $n$ & $\begin{array}{l}\text { Minimum mean } \\
\text { extension rate } \\
\left(\mathrm{cm} \mathrm{yr}^{-1}\right)\end{array}$ & $\begin{array}{l}\text { Maximum mean } \\
\text { extension rate } \\
\left(\mathrm{cm} \mathrm{yr}^{-1}\right)\end{array}$ & $\begin{array}{c}\text { Mean extension } \\
\text { rate } \\
\left(\mathrm{cm} \mathrm{yr}^{-1}\right)\end{array}$ & $\begin{array}{l}\text { Minimum } \\
\text { bulk density } \\
\left(\mathrm{g} \mathrm{cm}^{-3}\right)\end{array}$ & $\begin{array}{l}\text { Maximum } \\
\text { bulk density } \\
\left(\mathrm{g} \mathrm{cm}^{-3}\right)\end{array}$ & $\begin{array}{c}\text { Mean bulk } \\
\text { density } \\
\left(\mathrm{g} \mathrm{cm}^{-3}\right)\end{array}$ & $\begin{array}{c}\text { Minimum } \\
\text { calcification rate } \\
\left(\mathrm{g} \mathrm{cm}^{-2} \mathrm{yr}^{-1}\right)\end{array}$ & $\begin{array}{c}\text { Maximum } \\
\text { calcification rate } \\
\left(\mathrm{g} \mathrm{cm}^{-2} \mathrm{yr}^{-1}\right)\end{array}$ & $\begin{array}{c}\text { Mean } \\
\text { calcification rate } \\
\left(\mathrm{g} \mathrm{cm}^{-2} \mathrm{yr}^{-1}\right)\end{array}$ \\
\hline Orbicella $^{1}$ & 80 & 0.38 & 1.44 & $0.91 \pm 0.23$ & 0.78 & 1.94 & $1.37 \pm 0.24$ & 0.65 & 1.78 & $1.22 \pm 0.25$ \\
\hline $\begin{array}{l}\text { "Diplorial } \\
\text { Pseudodiploria"2 }\end{array}$ & 8 & 0.30 & 0.40 & $\mathbf{0 . 3 5} \pm 0.04$ & 0.97 & 1.70 & $1.27 \pm 0.31$ & 0.31 & 0.68 & $0.45 \pm 0.14$ \\
\hline $\begin{array}{l}\text { Porites } \\
\text { (W-Atlantic) }^{3}\end{array}$ & 15 & 0.28 & 0.48 & $0.37 \pm 0.07$ & 1.10 & 1.72 & $1.44 \pm 0.20$ & 0.31 & 0.77 & $0.53 \pm 0.14$ \\
\hline $\begin{array}{l}\text { Porites } \\
\text { (Indo-Pacific) }^{4}\end{array}$ & 78 & 0.30 & 2.38 & $1.28 \pm 0.50$ & 1.01 & 1.90 & $1.30 \pm 0.16$ & 0.56 & 2.82 & $1.67 \pm 0.49$ \\
\hline $\begin{array}{l}\text { Solenastrea } \\
{\text { (Florida Bay, recent })^{5}}^{5}\end{array}$ & 1 & & & 0.54 & & & 1.07 & & & 0.57 \\
\hline $\begin{array}{l}\text { Solenastrea }^{5} \\
(1.2,1.8,2.9,3.2 \mathrm{Ma})\end{array}$ & 12 & 0.22 & 0.83 & $0.42 \pm 0.17$ & 0.55 & 1.22 & $0.87 \pm 0.22$ & 0.20 & 0.97 & 0.38 \\
\hline $\begin{array}{l}\text { Orbicella }^{5} \\
(1.2,2.9 \mathrm{Ma})\end{array}$ & 2 & 0.16 & 0.64 & 0.40 & 0.76 & 1.14 & 0.95 & 0.18 & 0.48 & 0.33 \\
\hline $\begin{array}{l}\text { Porites } \\
(2.9 \mathrm{Ma})^{5}\end{array}$ & 1 & & & 0.89 & & & 0.60 & & & 0.54 \\
\hline
\end{tabular}

from those of Solenastrea according to visual assessment (Fig. 4). With regard to variability over geological time, extension rate, bulk density and calcification rate of the three genera Solenastrea, Orbicella and Porites from the Florida platform were plotted according to four time slices 3.2, 2.9, 1.8, and 1.2 Ma (Fig. 5, Tables 1, 2), and all calcification data were found to be indistinguishable among time slices according to ANOVA $(p>0.05)$. Published extension rates of $z$ corals reported from various other fossil low-latitude sites of the WA region are $\sim 0.3 \mathrm{~cm} \mathrm{yr}^{-1}$ in late Miocene reefs (Denniston et al., 2008b) and range from 0.3 to $0.8 \mathrm{~cm} \mathrm{yr}^{-1}$ in Pliocene units (Johnson and Pérez, 2006), whereas they were 0.2 and $1.0 \mathrm{~cm} \mathrm{yr}^{-1}$ in the Florida Reef Tract (FRT) during the late Pleistocene (0.13 Ma; Gischler et al., 2009). As such, they are all consistent with the low extension rates reported by our study (Fig. 4). Importantly, skeletal density data are not available from these sites due to pervasive diagenetic alterations, and therefore, skeletal density and calcification rates are unknown.

For the recent time slice $(0 \mathrm{Ma})$ we use analogue data from southern Florida published in the literature and complemented in part by one new set of average values (FB-6) published here for the first time (Table 4).

The extension rates of recent Solenastrea from FB range from 0.51 to $0.89 \mathrm{~cm} \mathrm{yr}^{-1}$ and are fully within the range found in the Pliocene and Pleistocene corals (Fig. 5). Density values have not been published from FB $z$ corals so far; we measured a density of $1.07 \mathrm{~g} \mathrm{~cm}^{-3}$ (Table 2) which is compatible with fossil Solenastrea. The same is true for the Orbicella from FRT as compared to the two fossil Orbicella, whereas the density records available from the FRT-Porites are substantially above that from the fossil Porites which is near the lower end of the spectrum (Fig. 5, Table 4). Finally, calcification rates of all three taxa of the recent $z$ corals in FB and FRT tend to be above the Plio-Pleistocene reconstructions (Fig. 5), and the average of all recent corals is significantly higher than the fossil average value $(p<0.05)$. From these observations the following three generalisations can be made: (1) the extension rates of the fossil $z$ corals are indistinguishable from those of the recent corals, and no distinction exists between FB and FRT, nearshore and offshore. (2) Bulk density is essentially the same in recent and fossil Florida $z$ corals, although some tendency towards higher bulk density as compared to the fossils may exist. (3) The calcification rates of the recent $z$ corals are all higher than those of the fossils (Fig. 5).

Stable isotope proxy data of the growth environments from the corals used here for calcification records were described and interpreted in a companion paper (Brachert et al., 2016) and will not be repeated in detail. For estimates of SSTs, an equation using skeletal $\delta^{18} \mathrm{O}$ calibrated for Orbicella from FRT was applied (Leder et al., 1996) and making the assumption of a constant value of $\delta^{18} \mathrm{O}_{\text {water }}=1.1 \%$ (recent FRT water) for all relevant interglacials (Brachert et al., 2016). On this basis, we found average annual SSTs between 19 and $26^{\circ} \mathrm{C}$ which were likely moderated by intermittent upwelling. Reconstructed temperatures display a negative correlation with annual extension rates $(p<0.05)$ and a positive relationship with bulk density $(p<0.05)$. In contrast, no clear relation has been found between SST and calcification rate $(p>0.05)$, although visual inspection suggests an inverse correlation (Fig. 6). Making other assumptions for $\delta^{18} \mathrm{O}_{\text {water }}$ (but keeping the value constant for all specimens) will yield other temperature values, but the range of values between minima and maxima of average annual temperatures will remain unaffected. 

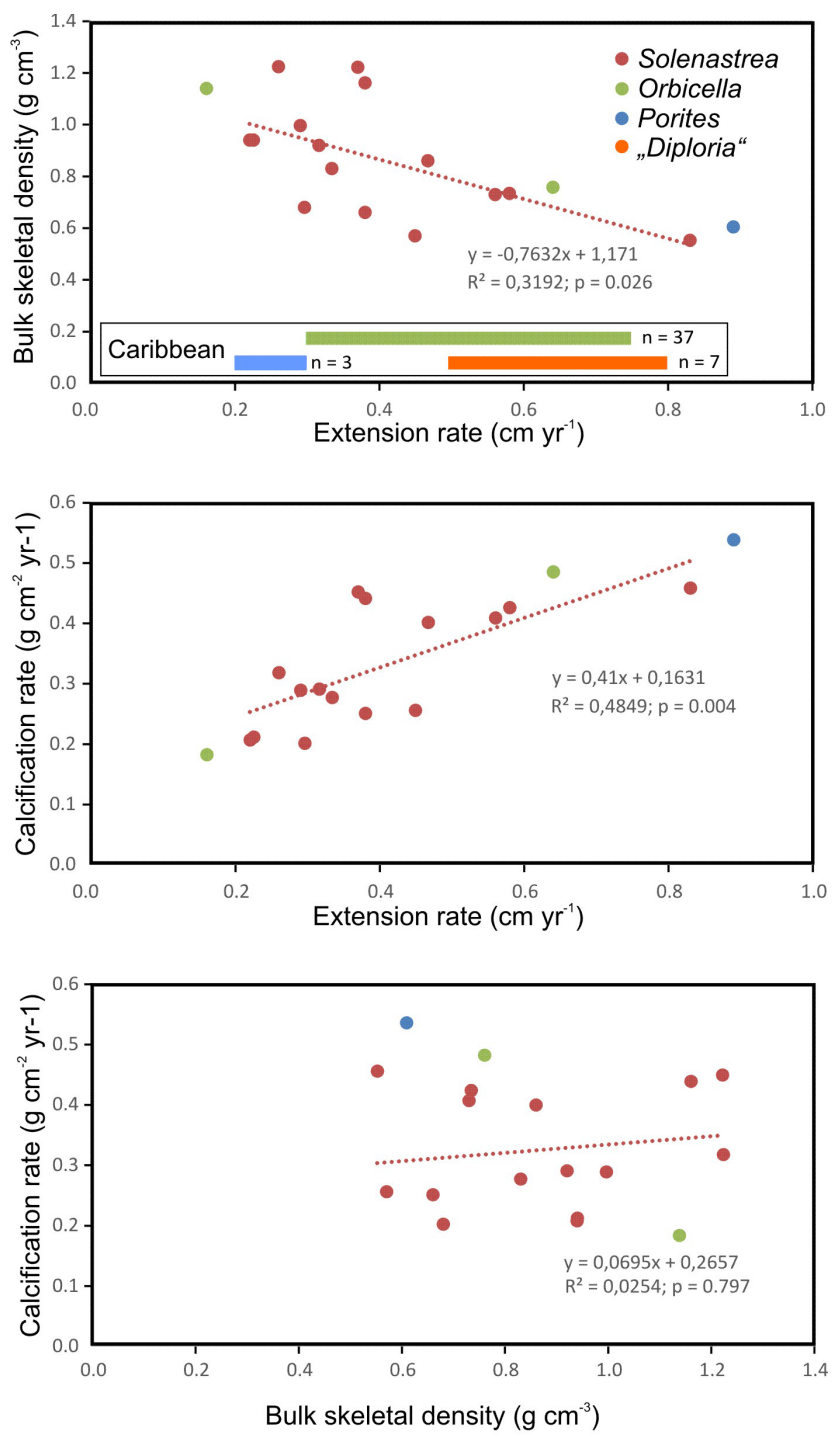

Figure 4. Calcification systematics in three Pliocene and Pleistocene $z$ coral genera from the Florida Platform. Inset summarizes published extension rates from the Pliocene of the Caribbean region; corresponding density values and calcification rates are not available (Johnson and Pérez, 2006). "Diploria" refers to the two taxa Diploria and Pseudodiploria (Budd et al., 2012).

\subsection{Significance of the calcification data}

Calcification of $z$ corals responds to a complex array of environmental factors acting in concert as to control net calcification (Lough and Cooper, 2011). Next to water temperature, these factors include water depth, wave exposure, admixtures of "inimical waters" from carbonate bank interiors, high and low salinity or freshwater discharge, nutrient concentration, $\mathrm{pH}$ and aragonite saturation and ocean region; Cohen and Holcomb, 2009; D'Olivio et al., 2015; FerrierPagès et al., 2000; Ginsburg and Shinn, 1964; Gladfelter et al., 1978; Hofmann et al., 2011; Johnson and Pérez, 2006;
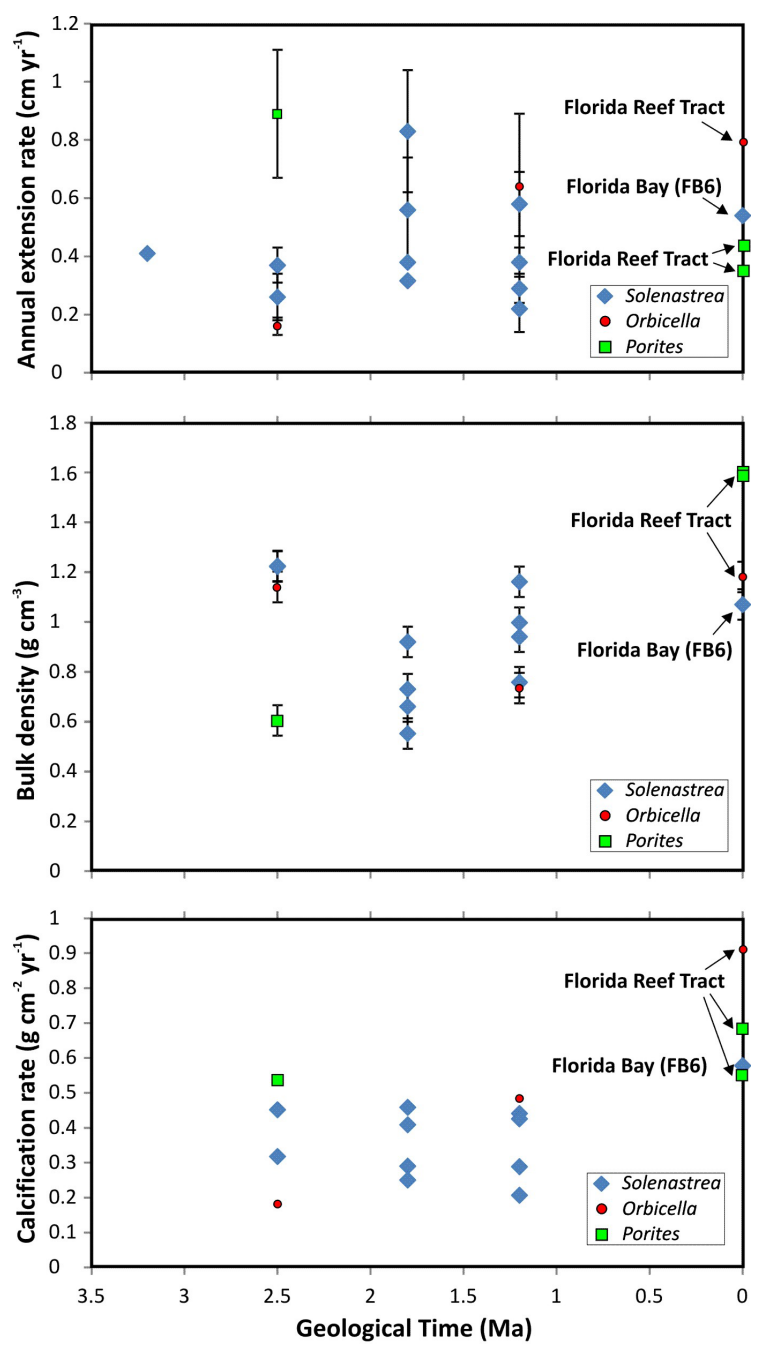

Figure 5. Temporal variation of the mean extension rate $( \pm 1 \sigma)$, bulk density and mean calcification rate in three $z$ coral genera (Solenastrea, Orbicella, Porites) from the Pliocene-Pleistocene Florida platform. Recent data from (Helmle et al., 2011; Hudson et al., 1989; Manzello et al., 2015a; Swart et al., 1996) and own materials (Florida Bay).

Klein et al., 1993; Lough and Cooper, 2011; Shinn, 1966). Thus, low calcification rates of the fossil corals can have multiple causes which are eventually hard to reconstruct. In attempting to sort out small-scale effects along environmental gradients, patterns related to taxonomy and non-linear calcification responses, we use a big picture approach beyond environmental gradients and regional acclimatisation effects and compare the reconstructed growth parameters within the frame of measured systems in southern Florida, the WA and IP (see methods section for data sources). 

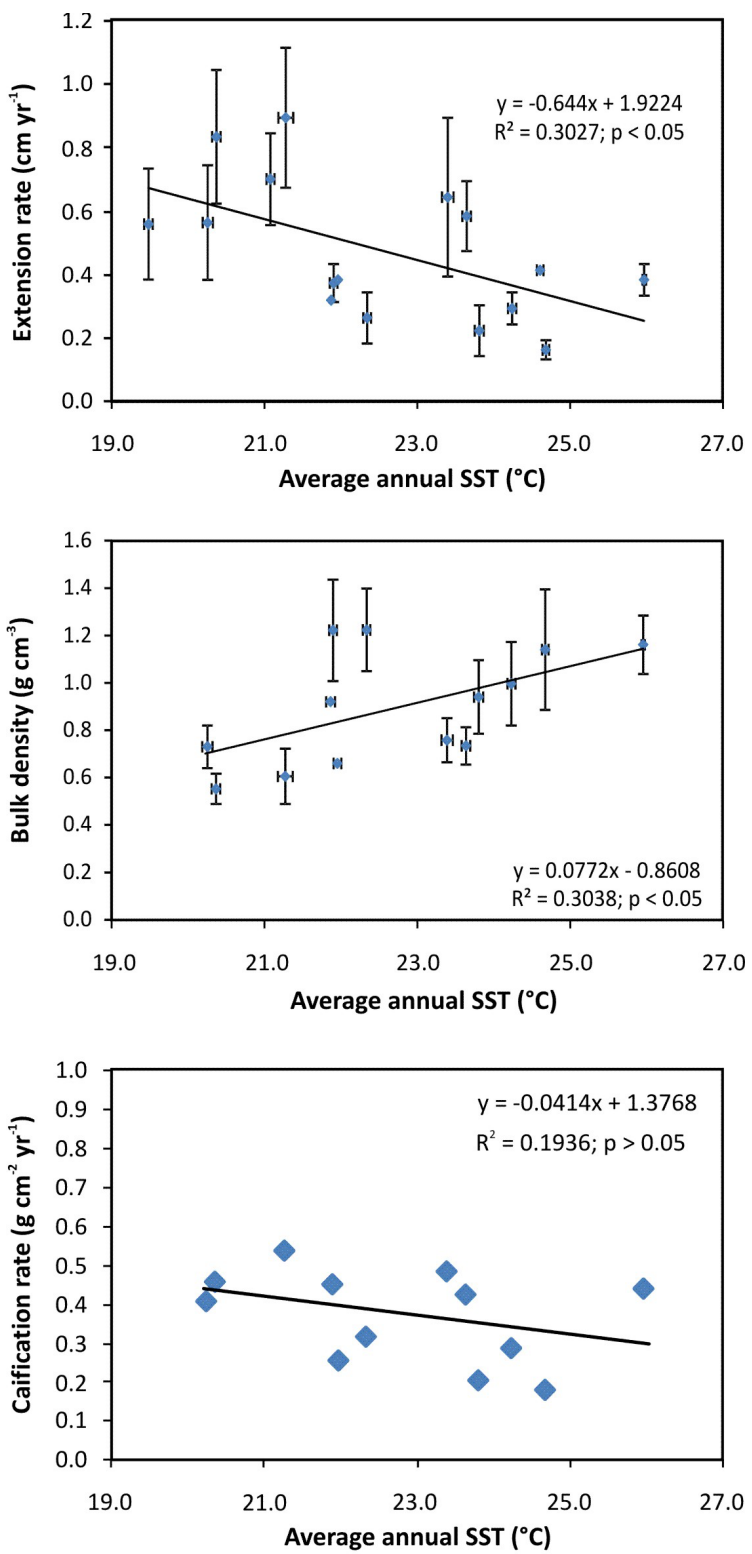

Figure 6. Diagrams showing annual extension rate $\left(\mathrm{cm} \mathrm{yr}^{-1}\right)$, bulk density $\left(\mathrm{g} \mathrm{cm}^{-3}\right)$ and annual calcification rate $\left(\mathrm{g} \mathrm{cm}^{-2} \mathrm{yr}^{-1}\right)$ with water temperature inferred from published $\delta^{18} \mathrm{O}$ values (Brachert et al., 2016).

\subsection{Environmental effects on calcification in recent and fossil $z$ corals from southern Florida}

We use modern analogue data from southern Florida for an evaluation of the calcification rates documented here for $z$ corals from Pliocene and Pleistocene units of the Florida Platform. In southern Florida, environments of $z$ coral growth range from the salinity stressed environment of the FB where $z$ corals only thrive within the most marine parts, to the open settings of the FRT variably affected by the outflow of "inimical" waters from the interior bank. Within this region, the highest rates of outflow of bankwater occur in the Middle Florida Keys where also the lowest calcification rates have been observed (Manzello et al., 2015a). Negative interference by inimical bank waters with $z$ coral growth has been hypothesised, therefore, to be smaller in offshore reefs $(>4.5 \mathrm{~km}$ from coast) compared to inshore reefs $(<4.5 \mathrm{~km}$ from coast). Nonetheless, long-term data averaged from several Porites colonies (Manzello et al., 2015a) do not indicate to a measurable negative spatial onshore-offshore effect on $z$ coral calcification. A proximality effect is also not inherent to the averaged analogue data shown in Fig. 5: although low calcification of Solenastrea in FB may be considered compatible with the inimical bank water hypothesis, even lower calcification rates of Porites from an offshore reef is clearly not. Apparently, small-scale spatial stress effects reported in the literature seem to be averaged out from the big picture. Because also no difference in calcification responses to environmental effects was found between Orbicella cavernosa and Porites astreoides (Manzello et al., 2015a), we consider the fossil data and recent analog data homogeneous entities not biased by systematic-taxonomical effects. From this line of reasoning we conclude the low calcification rates of the long-term fossil record from southern Florida not to reflect a restricted growth environment.

\subsection{Descriptive patterns of calcification in recent and fossil $z$ corals}

The calcification records presented by this study have been classified according to three descriptive patterns: (1) a negative relationship of extension rate with density being fully compatible with patterns of recent Orbicella. In recent Porites, the situation is more complex, because the pattern is documented only in the IP (Lough, 2008), but not in the WA (Elizalde-Rendon et al., 2010). (2) Extension rate and calcification rate showing a positive relation has been described also in recent Porites from the WA and IP (Elizalde-Rendon et al., 2010; Lough, 2008), but not in Orbicella from the WA which differ by a negative slope (Carricart-Ganivet, 2004). This is a surprising result, because the skeletal organization of Solenastrea closely resembles that of Orbicella and differs significantly from Porites, a pattern which was expected to be reflected in the systematics of calcification. (3) The fossil Solenastrea and recent Orbicella and Porites display deviating relationships with regard to bulk density and calcification rates: while the fossil Solenastrea shows no relationship, it is positive in Orbicella and WA-Porites but negative in IP-Porites (Carricart-Ganivet, 2004; Elizalde-Rendon et al., 2010; Lough, 2008). When plotted against water temperatures, the three calcification parameters and qualitative trends of the fossils are rather consistent with those of recent Orbicella from the WA (Carricart-Ganivet, 2004), both, in terms of the overall effects of temperature on extension rate and on bulk density. They differ, however, by the absence of a temperature control on calcification rates (or the presence 
of a likely negative slope according to visual inspection) in the fossils.

\subsection{Comparative analysis of fossil and recent $z$ coral calcification}

Calcification rates recorded by the fossil $z$ corals are conspicuously low as compared to recent $z$ corals from Florida (Fig. 5) which may represent, therefore, possibly no suitable analogue system. First of all, it should be noted, however, that the calcification data from the fossil Solenastrea (plus Orbicella and Porites) appear to be from a larger window of average annual temperatures $\left(\sim 7^{\circ} \mathrm{C}\right)$ than covered by field studies on recent $z$ coral growth. Temperature differences behind growth data from southern Florida are rather small, and even growth data collected in the Gulf of Mexico and the Caribbean Sea both cover small gradients of average annual SSTs $\left(\sim 1^{\circ} \mathrm{C}\right.$ ) where Orbicella (Orbicella annularis) display positive calcification responses with increasing SST (Carricart-Ganivet, 2004). Although calcification rates are the same in both regions, average annual SSTs differ by $\sim 2{ }^{\circ} \mathrm{C}$ and likely reflect the acclimatisation of the same morphological taxon to regionally different SST regimes. Thus, acclimatisation effects on calcification seem to play a role within rather small observational scales. Within the same region, another species of the same genus (Orbicella falveolata), however, responds with declining calcification to this subtle gradient of $\sim 1{ }^{\circ} \mathrm{C}$ of average annual SST change (Carricart-Ganivet et al., 2012), either because acclimatisation is not yet fully accomplished, or because the SST regime is near the upper threshold of ecological tolerance of $O$. falveolata allowing no further positive acclimatisation. We assume, the latter is more likely and, therefore, calcification responses to SST seem to be non-linear over the full range of ecological tolerance of this and other taxa. This sort of non-linear response of calcification has been predicted by a modelling study on the ecological tolerance of Orbicella over a temperature window of $3-4{ }^{\circ} \mathrm{C}$ (Worum et al., 2007) and is also well documented by comprehensive field studies on Porites from the Great Barrier Reef system (IP; Cooper et al., 2008; De'ath et al., 2009, 2013). The tipping point between increases and decreases of calcification rates was found to be between 26 and $27^{\circ} \mathrm{C}$ for Porites and Orbicella (Carricart-Ganivet et al., 2012; Cooper et al., 2008), or 28 $29^{\circ} \mathrm{C}$ according to modelling (Worum et al., 2007). This kind of large-scale observational data seems essential for interpreting fossil calcification data and, therefore, we discuss the calcification data in the context of the entire WA and IP.

\subsubsection{Florida and Western Atlantic}

Within the larger context of the WA, all parameters of calcification are higher in the recent $z$ corals than in the fossil $z$ corals. The extension rates of the fossils with a mean of $0.44 \pm 0.19 \mathrm{~cm} \mathrm{yr}^{-1}$ and ranging from 0.16 to
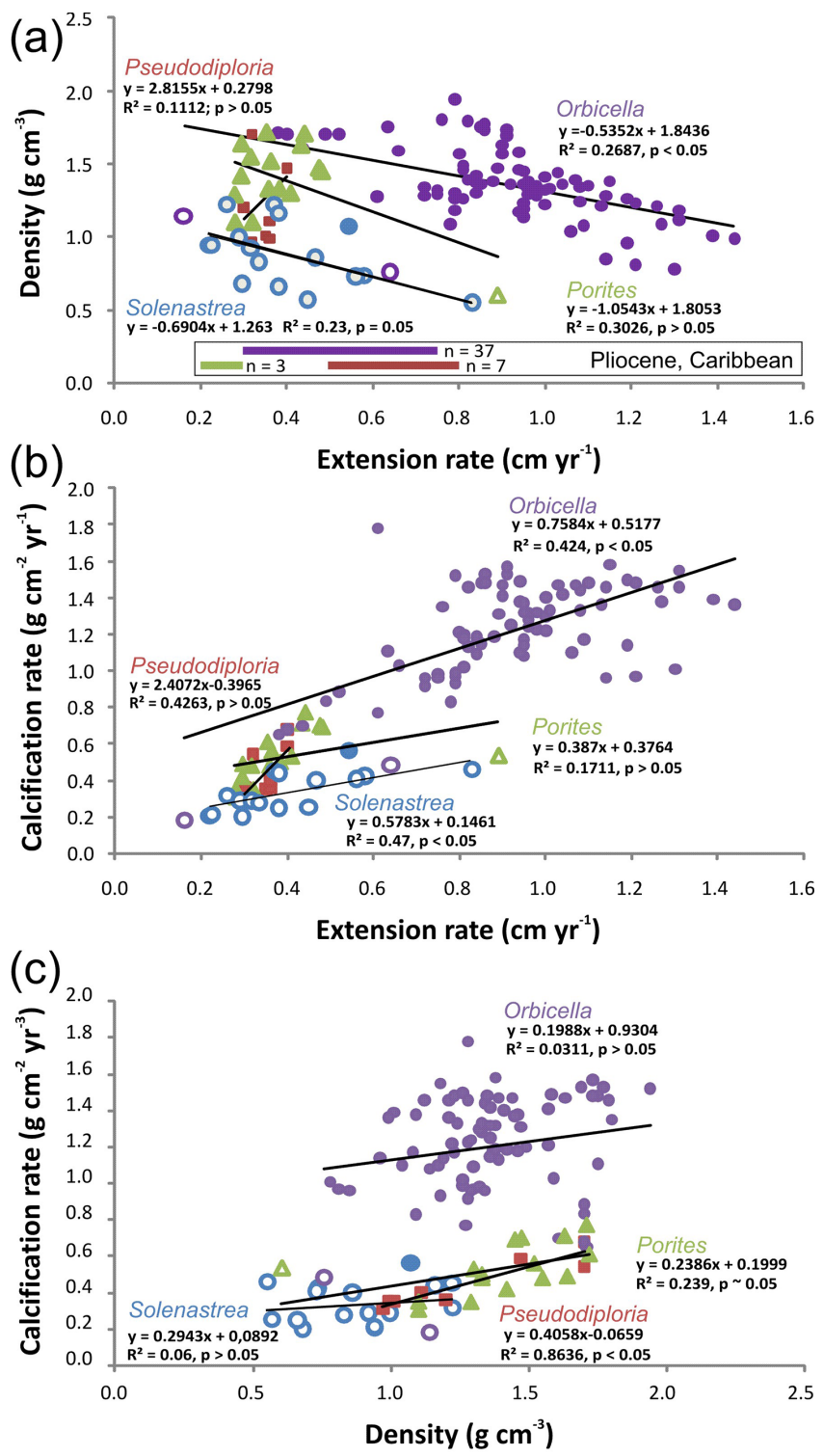

Figure 7. Mean extension rate, bulk skeletal density and mean calcification rate of reef corals sorted according to taxon and geological time (Western Atlantic region). Magenta: Orbicella, green: Porites, red: Diploria, blue: Solenastrea. Filled symbols: recent, open symbols: fossil. Recent corals compiled from the literature (CarricartGanivet et al., 2000; Carricart-Ganivet and Merino, 2001; Dodge and Brass, 1984; Elizalde-Rendon et al., 2010; Highsmith et al., 1983; Hudson et al., 1989; Logan and Tomascik, 1991; Mallela and Perry, 2007) and one unpublished record from Solenastrea (FB-6). Inset in uppermost panel shows range of extension rates of $z$ corals of Pliocene age in the Caribbean region (various taxa) for comparison (Johnson and Pérez, 2006). Note clustering of fossil corals at low extension rates, low density and low calcification rates.

$0.86 \mathrm{~cm} \mathrm{yr}^{-1}$ contrast with substantially higher mean values of $0.79 \pm 0.31 \mathrm{~cm} \mathrm{yr}^{-1}$ and ranges between 0.28 and $1.44 \mathrm{~cm} \mathrm{yr}^{-1}$ in the recent WA (Fig. 7; Table 3). Bulk density of the fossil $z$ corals displays a variability comparable to that 
Table 3. Bulk calcification data of recent reef corals in the Indo-Pacific and Western Atlantic together with fossil reef corals from Florida (USA). Bold: minimum values. Data sets listing only extension rates not included in this table.

\begin{tabular}{|c|c|c|c|c|c|c|c|c|c|c|}
\hline $\begin{array}{l}\text { Region with } \\
\text { geological age }\end{array}$ & $n$ & $\begin{array}{c}\text { Extension } \\
\min \\
\left(\mathrm{cm} \mathrm{yr}^{-1}\right)\end{array}$ & $\begin{array}{c}\text { Extension } \\
\max \\
\left(\mathrm{cm} \mathrm{yr}^{-1}\right)\end{array}$ & $\begin{array}{c}\text { Extension } \\
\text { mean } \\
\left(\mathrm{cm} \mathrm{yr}^{-1}\right)\end{array}$ & $\begin{array}{l}\text { Density } \\
\min \\
\left(\mathrm{g} \mathrm{cm}^{-3}\right)\end{array}$ & $\begin{array}{c}\text { Density } \\
\max \\
\left(\mathrm{g} \mathrm{cm}^{-3}\right)\end{array}$ & $\begin{array}{c}\text { Density } \\
\text { mean } \\
\left(\mathrm{g} \mathrm{cm}^{-3}\right)\end{array}$ & $\begin{array}{l}\text { Calcification rate } \\
\text { min } \\
\left(\mathrm{g} \mathrm{cm}^{-2} \mathrm{yr}^{-1}\right)\end{array}$ & $\begin{array}{l}\text { Calcification rate } \\
\max \\
\left(\mathrm{g} \mathrm{cm}^{-2} \mathrm{yr}^{-1}\right)\end{array}$ & $\begin{array}{l}\text { Calcification rate } \\
\text { mean } \\
\left(\mathrm{g} \mathrm{cm}^{-2} \mathrm{yr}^{-1}\right)\end{array}$ \\
\hline Indo-Pacific, recent $^{1}$ & 78 & 0.30 & 2.38 & $1.28 \pm 0.50$ & 1.01 & 1.90 & $1.30 \pm 0.16$ & 0.56 & 2.82 & $1.67 \pm 0.49$ \\
\hline Western Atlantic, recent ${ }^{2}$ & 103 & 0.28 & 1.44 & $0.79 \pm 0.31$ & 0.78 & 1.94 & $1.37 \pm 0.24$ & 0.31 & 1.78 & $1.06 \pm 0.38$ \\
\hline Florida Bay, recent ${ }^{3}$ & 1 & & & 0.54 & & & 1.07 & & & 0.57 \\
\hline $\begin{array}{l}\text { Florida (USA), } \\
\text { Plio-Pleistocene }^{3}\end{array}$ & 15 & 0.16 & 0.86 & $0.44 \pm 0.19$ & 0.55 & 1.22 & $0.86 \pm 0.22$ & 0.18 & 0.54 & $\mathbf{0 . 3 4} \pm \mathbf{0 . 1 1}$ \\
\hline
\end{tabular}

Data sources: ${ }^{1}$ Lough (2008); Fabricius et al. (2011); Bessat and Buiges (2001); Tanzil et al. (2009); Goodkin et al. (2011). ${ }^{2}$ Logan and Tomascik (1991); Elizalde-Rendon et al. (2010); Malella and Perry (2007); Carricart and Merino (2001); Carricart-Ganivet et al. (2000 and sources therein); Highsmith et al. (1983); Dodge and Brass (1984); Manzello (2015). ${ }^{3}$ This work.

Table 4. Calcification data from recent $z$ corals, southern Florida.

\begin{tabular}{lcccc}
\hline Taxon and site & $\begin{array}{c}\text { Extension rate } \\
\left(\mathrm{cm} \mathrm{yr}^{-1}\right)\end{array}$ & $\begin{array}{c}\text { Bulk density } \\
\left(\mathrm{g} \mathrm{cm}^{-3}\right)\end{array}$ & $\begin{array}{c}\text { Calcification rate } \\
\left(\mathrm{g} \mathrm{cm}^{-2} \mathrm{yr}^{-2}\right)\end{array}$ & Source \\
\hline $\begin{array}{l}\text { Solenastrea, } \\
\text { FB }\end{array}$ & 0.89 & $\mathrm{NA}$ & $\mathrm{NA}$ & Hudson et al. (1989) \\
$\begin{array}{l}\text { Solenastrea, } \\
\text { FB (FB-6) } \\
\begin{array}{l}\text { Porites, } \\
\text { FRT, inshore }\end{array}\end{array}$ & 0.51 & $\mathrm{NA}$ & $\mathrm{NA}$ & Swart et al. (1996) \\
$\begin{array}{l}\text { Porites, FRT, offshore } \\
\text { FRT, offshore } \\
\begin{array}{l}\text { Orbicella, } \\
\text { FRT }\end{array}\end{array}$ & 0.43 & 1.61 & 0.69 & Manzello et al. (2015a) \\
Solenastrea, FB (FB-6) & 0.35 & 1.58 & 0.55 & Manzello et al. (2015a) \\
\hline
\end{tabular}

of recent $z$ corals but the average from all fossil specimens $\left(0.86 \pm 0.22 \mathrm{~g} \mathrm{~cm}^{-3}\right)$ is substantially lower than in the recent $z$ corals $\left(1.37 \pm 0.24 \mathrm{~g} \mathrm{~cm}^{-3}\right)$ from the WA in our database (Fig. 7, Table 3). Maximum values $\left(1.22 \mathrm{~g} \mathrm{~cm}^{-3}\right)$ are lower than in the modern corals $\left(1.94 \mathrm{~g} \mathrm{~cm}^{-3}\right)$ and minimum values of $0.55 \mathrm{~g} \mathrm{~cm}^{-3}$ are also below minimum values of recent WA $z$ corals $\left(0.78 \mathrm{~g} \mathrm{~cm}^{-3}\right.$; Table 3$)$. Calcification rates inferred from this set of inputs for any given extension rate are $\sim 50 \%$ lower in fossils than those from modern $z$ corals.

The recent data from the WA are from the four genera (listed according to the number of data available) Orbicella, Porites, Diploria/Pseudodiploria and Solenastrea, and some of the discrepancy between fossils and recent $z$ corals, may therefore be an artifact of the database. When compared on the taxonomical genus level, extension rates of Porites (range $=0.28$ to 0.48 , mean $\left.=0.37+0.07 \mathrm{~cm} \mathrm{yr}^{-1}\right)$ and Diploria/Pesudodiploria (range $=0.30$ to 0.40, mean $=0.35+0.04 \mathrm{~cm} \mathrm{yr}^{-1}$ ) are significantly lower than those of Orbicella (range $=0.38$ to 1.44 , mean $\left.=0.91 \pm 0.23 \mathrm{~cm} \mathrm{yr}^{-1}, p<0.05\right)$ but are identical with regard to density (Porites: range $=1.10$ to 1.72 , mean $=1.44 \pm 0.20 \mathrm{~g} \mathrm{~cm}^{-3} ;$ Diploria/Pseudodiploria: range $=0.97$ to $1.70 ;$ mean $=1.27 \pm 0.31 \mathrm{~g} \mathrm{~cm}^{-3} ;$ Orbicella : range $=0.78$ to 1.94 , mean $\left.=1.37 \pm 0.24 \mathrm{~g} \mathrm{~cm}^{-3} ; p>0.05\right)$. Orbicella display a negative relationship between extension rate and bulk density $\left(R^{2}=0.27, p<0.05\right)$, whereas no such relationship has been documented for Porites $\left(R^{2}=0.30\right.$, $p>0.05)$ and Diploria/Pseudodiploria $\left(R^{2}=0.11, p>0.05\right)$ which are indistinguishable in their calcification data (Fig. 7). Remarkably, Porites and Diploria/Pseudodiploria are indistinguishable not only with regard to their general calcification relationship but also quantitatively in terms of absolute values and clearly differ from those of Orbicella, whose calcification rates are significantly higher at almost any given density (Fig. 7). Solenastrea is unusual due to its low extension rates (range $=0.22$ to 0.58 , mean $=0.43 \pm 0.19 \mathrm{~cm} \mathrm{yr}^{-1}$ ) and low bulk density (range $=0.55$ to 1.22 , mean $=0.88 \pm 0.22 \mathrm{~g} \mathrm{~cm}^{-3}$ ). Like Orbicella, extension rate and bulk density display a significant negative relationship $\left(R^{2}=0.23, p<0.05\right)$, whereas extension rate is positively correlated with calcification rate $\left(R^{2}=0.47\right.$, $p<0.05)$. Bulk density, on the other hand, displays no correlation with calcification rate $\left(R^{2}=0.06, p>0.05\right)$.

For the relationships described above, we find no consistent patterns of the parameters of calcification between recent and fossil specimens and between taxa. While the data from the recent Solenastrea specimen are similar to the data from fossil Solenastrea (Fig. 7), the single fossil Porites available is incompatible with recent Porites from the WA, both in terms of extension rate and bulk density, but plots together with fossil Solenastrea (Fig. 7). Also, the Pliocene Diploria/Pseudodiploria (only extension rates available from liter- 
(a)

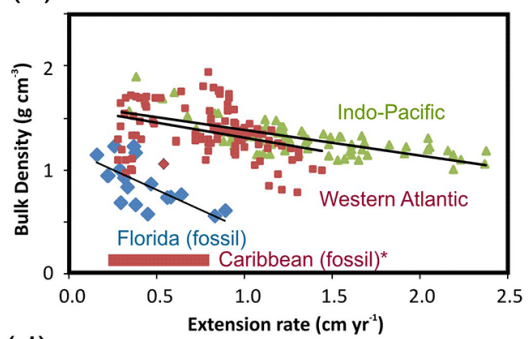

(d)

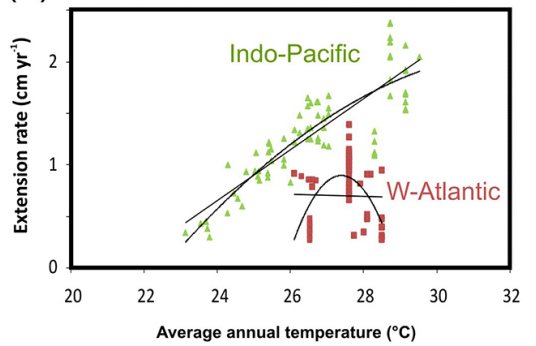

(b)

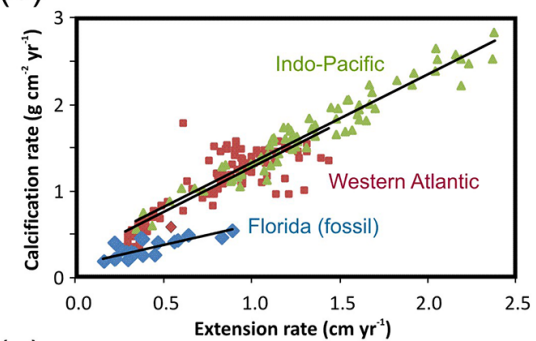

(e)

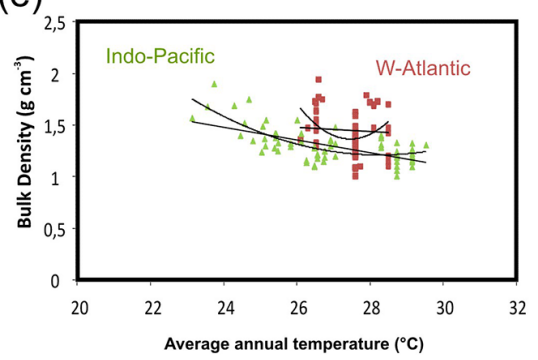

(c)

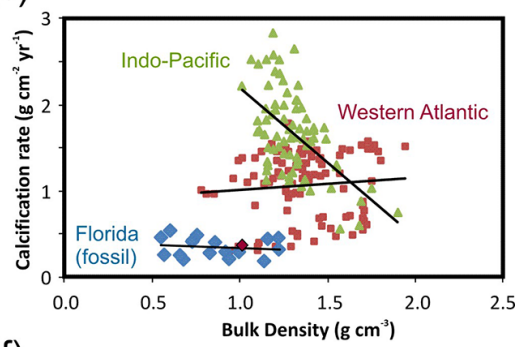

(f)

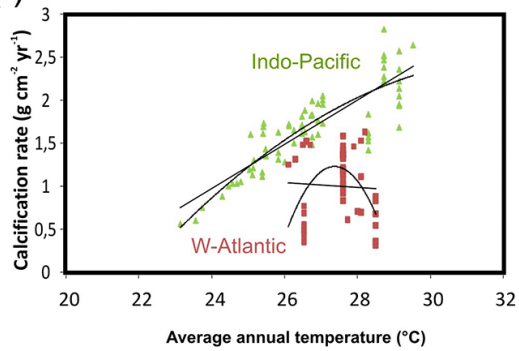

Figure 8. Extension rate, density and calcification rate of recent and fossil $z$ corals. Indo-Pacific (green triangles), Western Atlantic (red squares) and Florida fossils (blue diamonds). (a-c) Descriptive diagrams for relationships of extension rate, density, and calcification rate within the temperature windows shown in (d-f) for modern corals. Recent corals compiled from literature (Carricart-Ganivet et al., 2000; Carricart-Ganivet and Merino, 2001; Dodge and Brass, 1984; Elizalde-Rendon et al., 2010; Highsmith et al., 1983; Hudson et al., 1989; Lough, 2008; Mallela and Perry, 2007; Tanzil et al., 2009). ${ }^{*}$ Red horizontal bar in Fig. 7a summarizes published extension rates of $z$ corals of Pliocene age in the Caribbean region (various taxa) for comparison (Johnson and Pérez, 2006). (d-f) Extension rate, bulk density and calcification rates as a function of average annual temperature. Results of linear and quadratic polynomial regression are as follows: (a) Western Atlantic $y=-0.2958 \times+16072 ; R^{2}=0.1399, p<0.05$. Indo-Pacific $y=-0.2499 \times+1.6358 ; R^{2}=0.5167, p<0.05$. Florida (fossils) $y=-0.7607 \times+1.2774 ; R^{2}=0.4297, p<0.05$. (b) Western Atlantic $y=1.0235 \times+0.2545 ; R^{2}=0.6956, p<0.05$. Indo-Pacific $y=$ $1.0212 \times+0.3064 ; R^{2}=0.9327, p<0.05$. Florida (fossils) $y=0.4961 \times+0.1648 ; R^{2}=0.3171, p<0.05$. (c) Western Atlantic $y=0.1428 \times$ $+0.868 ; R^{2}=0.0084, p>0.05$. Indo-Pacific $y=-1.7219 \times+3.9122 ; R^{2}=0.3204, p<0.05$. Florida (fossils) $y=-0.0779 \times+0.4058$; $R^{2}=0.0233, p>0.05$. (d) Western Atlantic $y=-0.3747 x^{2}+20.525 \times-280.21 ; R^{2}=0.3524 ; p<0.05$ and $y=-0.0104 \times+0.9913$; $R^{2}=0.0006 ; p>0.05$. Indo-Pacific $y=-0.0203 x^{2}+.3294 \times-19.628 ; R^{2}=0.7519 ; p<0.05$ and $y=0.2472 \times-5.282 ; R^{2}=0.7376 ;$ $p<0.05$. (e) Western Atlantic $y=0.1588 x^{2}-8,7235 x \times+121.16 ; R^{2}=0.1128 ; p>0.05$ and $y=-0.0193 \times+1.9758 ; R^{2}=0.0036$; $p>0.05$. Indo-Pacific $y=0.0206 x^{2}-1.1664 \times+17.691 ; R^{2}=0.5101 ; p<0.05$ and $y=-0.0613 \times+2.9539 ; R^{2}=0.3885 ; p<0.05$. (f) Western Atlantic $y=-0.4333 x^{2}+23.722 \times-323.44 ; R^{2}=0.2699 ; p<0.05$ and $y=-0.0282 \times+1.7778 ; R^{2}=0.0025 ; p>0.05$. IndoPacific $y=-0.0223 x^{2}+1.4534 \times-21.144 ; R^{2}=0.7476 ; p<0.05$ and $y=0.2566 \times-5.1844 ; R^{2}=0.7322 ; p<0.05$.

ature data) clearly differ from their recent counterparts with significantly higher extension rates (Fig. 7). With regard to Orbicella, bulk density of the two fossil specimens available is lower at any given extension rate than in the recent Orbicella, but consistent with fossil Solenastrea (Fig. 7). In extension rate vs. bulk density space, we observe a duality between recent and fossil $z$ corals, rather than any taxonomical distinction. With regard to calcification rates, fossils also have lower values at any given extension rate than recent $z$ corals (Fig. 7). On the other hand, no clear separation exists between fossils and recent $z$ corals with regard to bulk density vs. calcification rate (Fig. 7).

\subsubsection{Indo-Pacific}

Extension rates of recent $z$ corals documented by our literature review for the WA (various taxa) and IP (Porites only) have a broad range of values from 0.28 to $2.38 \mathrm{~cm} \mathrm{yr}^{-1}$, how- ever, $z$ corals of the WA have significantly lower mean extension rates $\left(0.28 \pm 1.44\right.$, mean: $\left.0.79 \pm 0.31 \mathrm{~cm} \mathrm{yr}^{-1}\right)$ than those of the IP $\left(0.30 \pm 2.38\right.$, mean: $1.28 \pm 0.50 \mathrm{~cm} \mathrm{yr}^{-1}$, $p<0.05$; Table 3). Fossil corals have lower values than the recent corals $\left(0.16-0.89\right.$, mean: $0.45 \pm 0.20 \mathrm{~cm} \mathrm{yr}^{-1}$, $p<0.05$ ), including those from the WA, and some of the fossils have the smallest values recorded (Fig. 8a). With regard to density, there is a broad range of values; however, no significant difference exists among the WA (0.78-1.94, mean: $1.37 \pm 0.24 \mathrm{~g} \mathrm{~cm}^{-3}$ ) and IP $z$ corals (1.01-1.90, mean: $\left.1.30 \pm 0.16 \mathrm{~g} \mathrm{~cm}^{-3}, p>0.05\right)$, although the range of values is larger in the IP. Fossil corals have a similar range but clearly have significantly lower bulk density than the recent corals $(p<0.05)$ and also have the lowest minimum values of bulk density recorded $\left(0.55-1.22\right.$, mean: $0.86 \pm 0.22 \mathrm{~g} \mathrm{~cm}^{-3}$; Table 2). The recent $z$ corals of the WA and IP show significant negative correlations between extension rate and density with an identical slope $(f$ test; $p<0.05)$ and intercept. 
While the correlation in the IP $z$ coral data is highly significant $\left(R^{2}=0.52, p<0.05\right)$, it is weaker but still significant in the WA data $\left(R^{2}=0.14, p<0.05\right.$; Fig. 8a). The fossil reef corals show a significant negative relationship between extension rate and bulk density defined by linear regression as well, but the slope is steeper ( $f$ test; $p>0.05$ ) than in the recent corals $\left(R^{2}=0.43, p<0.05\right.$; Fig. $\left.8 \mathrm{a}\right)$.

Calcification rates of $z$ corals have a large range of values from 0.18 to $2.82 \mathrm{~g} \mathrm{~cm}^{-2} \mathrm{yr}^{-1}$ (Table 2). In recent and fossil $z$ corals, there is a significant positive correlation between extension and calcification rate $(p<0.05)$. In recent WA corals, calcification rates $(0.31-1.78$, mean: $1.06 \pm 0.38 \mathrm{~g} \mathrm{~cm}^{-2} \mathrm{yr}^{-1}$ ) remain clearly below those of the IP (0.56-2.82, mean: $\left.1.67 \pm 0.49 \mathrm{~cm}^{-2} \mathrm{yr}^{-1}\right)$ because of higher extension rates. Importantly, the slope of the relationship is identical ( $f$ test; $p<0.05$ ) in the WA and IP and the relationships are highly significant $\left(R^{2}=0.93\right.$ and $0.70, p<0.05$, respectively), whereas the slope of the relationship is smaller by $\sim 50 \%$ ( $f$ test; $p>0.05$ ) in the fossil corals (Fig. 8b). No such simple relationships exist between density and calcification rate. In the IP, there is a significant negative relation between density and calcification $\left(R^{2}=0.32, p<0.05\right)$, whereas in the WA, there is no relationship $\left(R^{2}=0.00, p>0.05\right.$; Fig. 8c $)$. Therefore, variations in calcification rates in the latter region are entirely driven by changes in extension rates, whereas in the IP, it is driven by both extension rates and bulk density, and decreasing density weakens the effect of increased extension on calcification. In the data from the Florida fossils no relationship of density was found with calcification rate $\left(R^{2}=0.02, p>0.05\right)$ which means that changes of calcification rate fully depend on variable extension and the pattern in essence resembles that of the WA (Fig. 8b, c).

Importantly, the recent $z$ corals from the WA display significantly lower values and a smaller range of values of all three calcification parameters (extension rate, bulk density, calcification rate) compared to the $z$ corals from the IP (Fig. 8d-f, Table 2). This corresponds with different temperature windows of $z$ coral distribution in the database. The WA corals in the database cover a rather small range of average annual temperatures between 26.4 and $28.6^{\circ} \mathrm{C}$, whereas the IP $z$ corals represent the spectrum of average annual water temperature between 23.0 and $29.6{ }^{\circ} \mathrm{C}$. Within these two temperature windows, differences between the WA and IP corals also pertain to patterns: In the IP, extension rates show a marked increase but bulk density decreases which combines to present a positive relationship of calcification rate with temperature. No such relationship exists in the WA corals (Fig. 8). Because of the established non-linearity of life processes in poikilothermic biota alike the reef corals (Goreau and Macfarlane, 1990; Grizzle et al., 2001; Townsend et al., 2008) linear regression is likely inappropriate for describing the statistics of calcification within the temperature windows documented by the data and beyond (Fig. 8d-f) and we have alternatively applied a quadratic function to the data. With respect to the WA data, this procedure results in an inverted parabolic relationship of extension rate with temperature $(p<0.05)$. Corresponding parabolic regressions for density and calcification rate are not significant $(p>0.05)$, and may be an effect of rather poor resolution of the temperature data in the database. The relationship is, however, consistent with calcification data from regional studies (Carricart-Ganivet, 2004; Carricart-Ganivet et al., 2012), but on a large scale.

\section{Lessons from the recent analogue}

The relationship of extension rate with density (slope and intercept of the regression) is identical in the WA and IP corals, although maximum extension rates tend to be in the IP (Fig. 8). Recent $z$ corals from the WA display enhanced variability of bulk density associated with low extension rates, which results from the noisy inputs of Diploria/Pseudodiploria and Porites, whereas Orbicella having higher extension rates forms a consistent population like Porites in the IP (Figs. 7, 8). It should be noted that the slope of linear regression is steeper in WA-Orbicella than IP-Porites according to an $f$ test ( $p<0.05$; Figs. $5,7 \mathrm{a}$ ). In contrast, the Florida fossil $z$ corals have significantly lower extension rates and mean bulk densities than all of their recent counterparts, and also have an extension rate/density relationship which differs from that of all recent $z$ corals in the database ( $p<0.05$; Fig. 6$)$.

With regard to calcification rates, all recent corals display an identical relationship between extension rate and calcification, irrespective of taxon or provenance, and this relationship is significantly different from that of the fossils ( $f$ test $p<0.05$; Fig. 8 b). The relationships of bulk density with calcification rate, however, significantly differ in the populations from the recent WA, the IP, and the Plio-Pleistocene of Florida, respectively (Fig. 8c).

From this discussion we conclude that recent and fossil $z$ corals clearly differ with regard to their relationships of extension rate with bulk density and that taxonomical peculiarities seem not to play a significant role for the big picture (Figs. 7, 8a). We further conclude that the relationship of extension rate with calcification rate is identical in recent $z$ corals from all ocean regions, but is significantly different between recent and fossil $z$ corals (Fig. 7b). Bulk density and calcification rate, on the other hand, display individual traits among the recent $z$ corals from the WA, the IP and the PlioPleistocene of Florida (Fig. 8c). 


\subsection{Low calcification rates due to high nutrients or low aragonite saturation?}

$Z$ coral skeletal calcification is closely linked with the saturation state of seawater with respect to aragonite, and low degrees of supersaturation have been demonstrated to cause low calcification rates (Cohen and Holcomb, 2009; Gattuso et al., 1998; Langdon et al., 2000). In the low latitudes, surface waters of upwelling regions have been shown to be low in $\Omega_{\text {aragonite }}$ (Furnas, 2011). Upwelling has been documented also for the Plio-Pleistocene interglacials of Florida (Brachert et al., 2016), and $z$ coral skeletons recording maximum upwelling according to their stable isotope composition, have the smallest density values but largest values of extension rate (Brachert et al., 2016). This conforms with findings from the Galapagos upwelling system, were $z$ coral skeletal density is reduced under maximum upwelling stresses, but extension rate is higher than predicted from the ambient SST (Manzello et al., 2014). The low volumes of cements in intra-skeletal porosity of the corals and the low degree of cementation of the Plio-Pleistocene shallow-marine carbonates may reflect the effects of phosphate poisoning to carbonate precipitation in an upwelling regime (Hallock and Schlager, 1986; Manzello et al., 2014), but the benthic assemblages and low amounts of bioerosion do not provide compelling evidence for high eutrophy. If anything, these findings support intermittent upwelling inferred from stable isotope data which has positively interfered with $z$ coral calcification on the Florida platform during the Plio-Pleistocene, but clearly documents minimal calcification rates to have coincided with episodes with minimum upwelling (Brachert et al., 2016). Thus, upwelling cannot be the prime reason for the observed low calcification rates.

Furthermore, the low extension rates of the PlioPleistocene $z$ corals from Florida are fully compatible with those published from fossil $z$ corals at various locations in the tropical WA (various taxa) which also range between 0.3 and $0.8 \mathrm{~cm} \mathrm{yr}^{-1}$ during the Pliocene (Johnson and Pérez, 2006), $\sim 0.3 \mathrm{~cm} \mathrm{yr}^{-1}$ in the late Miocene (Denniston et al., 2008b) and 0.2 and $1.0 \mathrm{~cm} \mathrm{yr}^{-1}$ in the FRT during the late Pleistocene (0.13 Ma; Gischler et al., 2009; Fig. 7g). For this reason, low extension rates recorded by the Florida fossils are representative of the tropical WA at that time and were as such a large-scale regional or perhaps even global phenomenon. Reasons for globally low $\mathrm{pH} / \mathrm{low} \Omega_{\text {aragonite }}$ in ambient water may be sought in high atmospheric $p \mathrm{CO}_{2}$ levels. However, for the last $3 \mathrm{Ma}$ after the mid-Pliocene climatic optimum ( $\sim 3 \mathrm{Ma})$, reconstructed $p \mathrm{CO}_{2}$ was near preindustrial levels and only during and before the climatic optimum it was at the levels predicted to exist by the end of this century (IPCC, 2013; Seki et al., 2010). For the long-term buffering effect of the ocean, $\Omega_{\text {aragonite }}$ has been suggested to have not been significantly different from the present day during the Plio-Pleistocene interglacials, however (Hönisch et al., 2012). On the other hand, substantial $p \mathrm{CO}_{2}$ changes have been documented over the glacial-interglacial cycles of the Quaternary (Petit et al., 1999), concomitant with changes in calcification of calcareous plankton (Barker and Elderfield, 2002; Beaufort et al., 2011). Thus, low $\Omega_{\text {aragonite may }}$ represent a potential driver of the observed low calcification rates.

\subsection{Low calcification rates due to heat stress?}

Next to $\Omega_{\text {aragonite, }}$, temperature is an important control of $z$ coral calcification in the world oceans. Given the simplification in our reconstruction of SSTs discussed above, the extension rates still display a negative correlation with the average annual SST $(p<0.05)$ and bulk density a positive relationship with SST $(p<0.05)$. In contrast, no clear relation has been found between SST and calcification rate $(p>0.05)$, although visual inspection suggests an inverse correlation (Fig. 8). This pattern is qualitatively rather consistent with recent Orbicella (Carricart-Ganivet, 2004), however, at a substantially larger temperature window in the fossil material and an absent relationship or likely negative correlation of calcification rate with temperature (Fig. 6).

Over the large temperature window of $6.9^{\circ} \mathrm{C}$ covered by the modern IP data, a pattern of changes driven by temperature has been documented using linear regression (Fig. 8df). In contrast, the temperature range documented by $z$ corals from the WA database covers only $2.2^{\circ} \mathrm{C}$ (Fig. 8d-f) and calcification data do not display any linear relationship. Instead of a linear fit, they can be approximated using a quadratic polynomial which should suggest the present temperature window realised by recent $z$ corals of the WA to cover more or less the ecological spectrum of this coral province. Low extension rates documented by fossil $z$ corals from Florida and many other locations of the Caribbean, therefore, potentially document temperatures either near their lower or upper levels of ecological tolerance. In our temperature reconstruction using skeletal $\delta^{18} \mathrm{O}$ values, we apply a value of $\delta^{18} \mathrm{O}_{\text {water }}$ which likely underestimates the actual SST because other methods consistently found SSTs of the WA warm pool $\sim 2{ }^{\circ} \mathrm{C}$ above present values during the last $5 \mathrm{Ma}$ (Fedorov et al., 2013; O’Brien et al., 2014). Low calcification rates in $z$ corals may, therefore, reflect warmer-thanpresent SSTs during the Plio-Pleistocene interglacials. Such an interpretation is consistent with concepts of nonlinear calcification responses to temperature in $z$ corals (Brachert et al., 2013; Gischler et al., 2009; Worum et al., 2007). Correspondingly, approaches describing coral calcification within temperature windows of $<1^{\circ} \mathrm{C}$ of annual temperature would not describe $z$ coral calcification over the full spectrum of ecological tolerance of a given species and may describe calcification near the optimum or lower and/or upper threshold of calcification only. In application of this concept, $z$ coral growth in the WA was likely under significant heat stress, and annual water temperatures $2{ }^{\circ} \mathrm{C}$ higher than at present were causing calcification rates $50 \%$ lower than present day. 
It should be noted also that upwelling has been ascribed a mitigating effect on SST stresses depending on the depth of upwelling or the timing during the year (Chollett et al., 2010; Riegl and Piller, 2003) and maximum extension rates and/or minimum density of the Florida $z$ corals coincided with a maximum of upwelling. Intermittent upwellings during the Plio-Pleistocene, therefore, seem to have created temporary refuges for $z$ corals by episodically mitigating heat stresses (Brachert et al., 2016). This finding supports notions of hot SSTs during the Eemian interglacial to have resulted in reef kills at equatorial latitudes and poleward migrations of many $z$ coral taxa (Kiessling et al., 2012). Our data also suggest recent coral reefs at equatorial latitudes to be potentially endangered from rising SSTs with ongoing climate change and ocean acidification (IPCC, 2013).

\section{Conclusions}

- This study presents quantitative records of calcification rates from Pliocene and Pleistocene interglacial reef corals ( $z$ corals).

- Z coral skeletons from Pliocene and Pleistocene precursors of the modern Florida carbonate platform display pristine preservation of stable isotope signatures and calcification data.

- Extension rates of Plio-Pleistocene specimens from Florida (various taxa) are remarkably low, but compatible with those of other tropical Caribbean settings at that time.

- Calcification data are undistinguishable among geological time slices (interglacials), but bulk density and calcification rate of recent $z$ corals from Florida are remarkably high compared to the fossils.

- Average calcification rates of Pliocene and Pleistocene specimens, irrespective of $z$ coral taxon, were only $50 \%$ of the recent values in the WA.

- The reasons behind low calcification rates during the Plio-Pleistocene interglacials are not clear but a lowerthan-recent saturation of seawater with aragonite or high water temperatures near the limits of ecological tolerance are likely candidates.

Author contributions. T. C. Brachert designed this research; field work was carried out by T. C. Brachert, M. Reuter and J. S. Klaus. Laboratory analyses were performed by T. C. Brachert, S. Krüger and M. Reuter. K. Helmle provided calcification records from a recent Solenastrea from Florida Bay. T. C. Brachert, M. Reuter and J. M. Lough wrote the paper.
Acknowledgements. Eduard Petuch (Florida Atlantic University, USA) provided some of the samples needed for this study. Kurt Schubert carefully prepared the coral slices and Jörg Lenzner made the SEM micrographs (both University of Leipzig, Germany). Adrian Immenhauser (University of Bochum, Germany) made valuable comments to an earlier manuscript and Christine Perrin (CNRS Moulis, France) is thanked for her suggestions on issues of skeletal alteration and preservation. We also thank the reviewers of the journal for their continual support and helpful suggestions. Funding by the Deutsche Forschungsgemeinschaft is gratefully acknowledged (BR 1153/13-1).

Edited by: T. Treude

Reviewed by: J. P. Carricart-Ganivet and two anonymous referees

\section{References}

Allison, N., Finch, A. A., and EIMF: $\delta^{11} \mathrm{~B}, \mathrm{Sr}, \mathrm{Mg}$ and B in a modern Porites coral: the relationship between calcification site $\mathrm{pH}$ and skeletal chemistry, Geochim. Cosmochim. Ac., 79, 19701800, 2010.

Allison, N., Finch, A. A., Webster, J. M., and Clague, D. A.: Palaeoenvironmental records from fossil corals: The effects of submarine diagenesis on temperature and climate estimates, Geochim. Cosmochim. Ac., 71, 4693-4703, 2007.

Allmon, W. D.: Nutrients, temperature, disturbance, and evolution: a model for the late Cenozoic marine record of the western Atlantic, Palaeogeogr. Palaeocl., 166, 9-26, 2001.

Allmon, W. D., Spizuco, M. P., and Jones, D. S.: Taphonomy and paleoenvironment of two turritellid-gastropod-rich beds, Pliocene of Florida, Lethaia, 28, 75-83, 1995.

Anagnostou, E., Sherrell, R. M., Gagnon, A., LaVigne, M., Field, M. P., and McDonough, W. F.: Seawater nutrient and carbonate ion concentrations recorded as $\mathrm{P} / \mathrm{Ca}, \mathrm{Ba} / \mathrm{Ca}$, and $\mathrm{U} / \mathrm{Ca}$ in the deep-sea coral Desmophyllum dianthus, Geochim. Cosmochim. Ac., 75, 2529-2543, 2011.

Baker, P. A. and Weber, J. N.: Coral growth rate: Variation with depth, Earth Planet. Sc. Lett., 27, 57-61, 1975.

Barker, C. E.: Fluid inclusions in the Pleistocene Miami Limestone, southeastern Florida: potentially misleading evidence of vadose diagenesis, Geological Society of America, Abstracts with Programs, 20, A119, 1986.

Barker, S. and Elderfield, H.: Foraminiferal Calcification Response to Glacial-Interglacial Changes in Atmospheric $\mathrm{CO}_{2}$, Science, 297, 833-836, 2002.

Bathurst, R. G. C.: Carbonate Sediments and their Diagenesis, Elsevier Science Publ. Co., New York, 1975.

Beaufort, L., Probert, I., de Garidel-Thoron, T., Bendif, E. M., RuizPino, D., Metzl, N., Goyet, C., Buchet, N., Coupel, P., Grelaud, M., Rost, B., Rickaby, R. E. M., and de Vargas, C.: Sensitivity of coccolithophores to carbonate chemistry and ocean acidification, Nature, 476, 80-83, 2011.

Bessat, F. and Buigues, D.: Two centuries of variation in coral growth in a massive Porites colony from Moorea (French Polynesia): a response of ocean-atmoshere variability from south central Pacific, Palaeogeogr. Palaeocl., 175, 381-392, 2001.

Böcker, A.: Interannual and seasonal climate variability recorded by reef corals, Plio/Pleistocene (Florida) and Mio/Pliocene (Do- 
minican Republic), Dissertation, Fakultät für Physik und Geowissenschaften, Universität Leipzig, Leipzig, 2014.

Brachert, T. C., Reuter, M., Felis, T., Kroeger, K. F., Lohmann, G., Micheels, A., and Fassoulas, C.: Porites corals from Crete (Greece) open a window into Late Miocene (10 Ma) seasonal and interannual climate variability, Earth Planet. Sc. Lett., 245, 8194, 2006a.

Brachert, T. C., Reuter, M., Kroeger, K. F., and Lough, J.: Coral growth bands: A new and easy to use paleothermometer in paleoenvironment analysis and paleoceanography (late Miocene, Greece), Paleoceanography 21, PA4217, doi:10.1029/2006PA001288, 2006b.

Brachert, T. C., Reuter, M., Krüger, S., Böcker, A., Lohmann, H., Mertz-Kraus, R., and Fassoulas, C.: Density banding in corals: barcodes of past and current climate change, Coral Reefs, 32, 1013-1023, 2013.

Brachert, T. C., Reuter, M., Krüger, S., Kirkerowicz, J., and Klaus, J. S.: Upwellings mitigated Plio-Pleistocene heat stress for reef corals on the Florida platform (USA), Biogeosciences, 13, 14691489, doi:10.5194/bg-13-1469-2016, 2016.

Brachert, T. C., Reuter, M., Krüger, S., Lohmann, H., Petuch, E. J., and Klaus, J. S.: A 4.2 Million years record of interglacial paleoclimate from sclerochronological data of Florida carbonate platform (Early Pliocene to recent), Global Planet. Change, 120, 54-64, 2014.

Budd, A. F., Fukami, H., Smith, N. D., and Knowlton, N.: Taxonomic classification of the reef coral family Mussidae (Cnidaria: Anthozoa: Scleractinia), Zool. J. Linn. Soc.-Lond., 166, 465529, 2012.

Cantin, N. E., Cohen, A. L., Karnauskas, K. B., Tarrant, A. M., and McCorkle, D. C.: Ocean warming slows coral growth in the central Red Sea, Science, 329, 322-325, 2010.

Carricart-Ganivet, J. P.: Sea surface temperature and the growth of the West Atlantic reef-building coral Montastraea annularis, J. Exp. Mar. Biol. Ecol., 302, 249-260, 2004.

Carricart-Ganivet, J. P., Beltrán-Torres, A. U., Merino, M., and Ruiz-Zárate, M. A.: Skeletal extension, density and calcification rate of the reef building coral Montastraea annularis (Ellis and Solander) in the Mexican Caribbean, B. Mar. Sci., 66, 215-224, 2000.

Carricart-Ganivet, J. P., Cabanillas-Terán, N., Cruz-Ortega, I., and Blanchon, P.: Sensitivity of calcification to thermal stress varies among genera of massive reef-building vorals, PLoS ONE, 7, 18, 2012.

Carricart-Ganivet, J. P. and Merino, M.: Growth responses of the reef-building coral Montastraea annularis along a gradient of continental influence in the southern Gulf of Mexico, B. Mar. Sci., 68, 133-146, 2001.

Chollett, I., Mumby, P. J., and Cortes, J.: Upwelling areas do not guarantee refuge for coral reefs in a warming world, Mar. Ecol.Prog. Ser., 416, 47-56, 2010.

Cohen, A. L. and Holcomb, M.: Why corals care about ocean acidification. Uncovering the mechanism, Oceanography, 22, 118127, 2009.

Constantz, B. R.: The primary surface area of corals and variations in their susceptibility to diagenesis, in: Reef Diagenesis, edited by: Schroeder, J. H. and Purser, B. H., Springer-Verlag, New York, 1986.
Cooper, T. F., De'Ath, G., Fabricius, K. E., and Lough, J. M.: Declining coral calcification in massive Porites in two nearshore regions of the northern Great Barrier Reef, Glob. Change Biol., 14, 529-538, 2008.

D’Olivo, J. P., McCulloch, M. T., Eggins, S. M., and Trotter, J.: Coral records of reef-water $\mathrm{pH}$ across the central Great Barrier Reef, Australia: assessing the influence of river runoff on inshore reefs, Biogeosciences, 12, 1223-1236, doi:10.5194/bg-12-12232015, 2015.

De'ath, G., Fabricius, K., and Lough, J.: Yes - Coral calcification rates have decreased in the last twenty-five years!, Mar. Geol., 346, 400-402, 2013.

De'ath, G., Lough, J. M., and Fabricius, K. E.: Declining Coral Calcification on the Great Barrier Reef, Science, 323, 116-119, 2009.

Denniston, R. F., Asmeron, Y., Polyak, V. Y., McNeill, D., Klaus, J. S., Cole, P., and Budd, A. F.: Caribbean chronostratigraphy constrained with $\mathrm{U}-\mathrm{Pb}$ and ${ }^{87} \mathrm{Sr} /{ }^{86} \mathrm{Sr}$ analysis of a Miocene coral, Geology, 36, 151-153, 2008a.

Denniston, R. F., Penn, S. C., and Budd, A. F.: Constraints on Late Miocene shallow marine seasonality for the Central Caribbean using oxygen isotopes and $\mathrm{Sr} / \mathrm{Ca}$ ratios in a fossil coral, in: Evolutionary stasis and change in the Dominican Republic Neogene, edited by: Nehm, R. H. and Budd, A. F., Topics in Geobiology, 30, Springer Science and business Media B.V., Heidelberg, 2008 b.

Dodge, R. E. and Brass, G. W.: Skeleton extension, density and calcification of the reef coral Montastrea annularis: St. Croix, U.S Virgin Islands, B. Mar. Sci., 34, 288-307, 1984.

Dowsett, H. J. and Cronin, T. M.: High eustatic sea level during the middle Pliocene: Evidence from the southeastern US Atlantic Coastal Plain, Geology, 18, 435-438, 1990.

Dullo, W.-C.: Progressive diagenetic sequence of aragonite structures: Pleistocene coral reefs and their modern counterparts on the eastern Red Sea coast, Saudi Arabia, Palaeontographica Americana, 54, 254-160, 1984.

Dustan, P.: Growth and form in the reef-building coral Montastrea annularis, Mar. Biol., 33, 101-107, 1975.

Elizalde-Rendon, E. M., Horta-Puga, G., Gonzalez-Diaz, P., and Carricart-Ganivet, J. P.: Growth characteristics of the reefbuilding coral Porites astreoides under different environmental conditions in the Western Atlantic, Coral Reefs, 29, 607-614, 2010.

Emslie, S. D. and Morgan, G. S.: A Catastrophic Death Assemblage and Paleoclimatic Implications of Pliocene Seabirds of Florida, Science, 264, 684-685, 1994.

Fabricius, K. E., Langdon, C., Uthicke, S., Humphrey, C., Noonan, S., De/'ath, G., Okazaki, R., Muehllehner, N., Glas, M. S., and Lough, J. M.: Losers and winners in coral reefs acclimatized to elevated carbon dioxide concentrations, Nature Climate Change, $1,165-169,2011$.

Fedorov, A. V., Brierley, C. M., Lawrence, K. T., Liu, Z., Dekens, P. S., and Ravelo, A. C.: Patterns and mechanisms of early Pliocene warmth, Nature, 496, 43-49, 2013.

Felis, T., Lohmann, G., Kuhnert, H., Lorenz, S. J., Scholz, D., Pätzold, J., Al-Rousan, S. A., and Al-Moghrabi, S. M.: Increased seasonality in Middle East temperatures during the last interglacial period, Nature, 429, 164-168, 2004 
Felis, T. and Pätzold, J.: Climate reconstructions from annually banded corals, in: Global environmental change in the ocean and on land, edited by: Shiyomi, M., Kawahata, H., Koizumi, H., Tsuda, A., and Awaya, Y., Terrapub, Tokyo, 2004.

Ferrier-Pagès, C., Gattuso, J.-P., Dallot, S., and Jaubert, J.: Effect of nutrient enrichment on growth and photosynthesis of the zooxanthellate coral Stylophora pistillata, Coral Reefs, 19, 103-113, 2000

Flügel, E.: Microfacies analysis of carbonate rocks. Analysis, interpretation and application, Springer Verlag, Heidelberg, 2004.

Furnas, J.: Upwelling and coral reefs, in: Encyclopedia of modern coral reefs - structure, form and process, edited by: Hopley, D., Encyclopedia of earth sciences series, Springer, Dordrecht, 2011.

Gattuso, J.-P., Frankignoulle, M., Bourge, I., Romaine, S., and Buddemeier, R. W.: Effect of calcium carbonate saturation of seawater on coral calcification, Global Planet. Change, 18, 37-46, 1998.

Ginsburg, R. N. and Shinn, E. A.: Distribution of the reef-building community in Florida and the Bahamas, Am. Assoc. Petr. Geol. B., 48, 527, 1964.

Gischler, E., Hudson, J., and Storz, D.: Growth of Pleistocene massive corals in south Florida: low skeletal extension-rates and possible ENSO, decadal, and multi-decadal cyclicities, Coral Reefs, 28, 823-830, 2009.

Gladfelter, E. H., Monahan, R. K., and Gladfelter, W. B.: Growth rates of five reef-building corals in the northeastern Caribbean, B. Mar. Sci., 28, 728-734, 1978.

Goodkin, N. F., Switzer, A. D., McCorry, D., DeVantier, L., D. True, J. D., Hughen, K. A., Angeline, N., and Yang, T. T.: Coral communities of Hong Kong: long-lived corals in a marginal reef environment, Mar. Ecol.-Prog. Ser., 426, 185-196, 2011.

Goreau, T. J. and Macfarlane, A. H.: Reduced growth rate of Montastrea annularis following the 1987-1988 coralbleaching event, Coral Reefs, 8, 211-215, 1990.

Gothmann, A. M., Stolarski, J., Adkins, J. F., Schoene, B., Dennis, K. J., Schrag, D. P., Mazur, M., and Bender, M. L.: Fossil corals as an archive of secular variations in seawater chemistry since the Mesozoic, Geochim. Cosmochim. Ac., 160, 188-208, 2015.

Graus, R. R. and Macintyre, I. G.: Variations in growth forms of the reef coral Montastrea annularis (Ellis \& Sollander): a quantitative evaluation of growth response to light distribution using computer simulation, in: The Atlantic Barrier Reef Ecosystem at Carrie Bow Cay, Belize, I, Structure and Communities, edited by: Rützler, K. and Macintyre, I. G., Smithsonian Contributions to the Marine Sciences No. 12, Washington, D.C., 1982.

Griffiths, N., Müller, W., Johnson, K. G., and Aguilera, O. A.: Evaluation of the effect of diagenetic cements on element/Ca ratios in aragonitic Early Miocene ( $\sim 16 \mathrm{Ma})$ Caribbean corals: Implications for "deep-time" palaeoenvironmental reconstructions, Palaeogeogr. Palaeocl., 369, 185-200, 2013.

Grizzle, R. E., Bricelj, V. M., and Shumway, S. E.: Physiological ecology of Mercenaria mercenaria, in: The biology of the hard clam, ediuted by: Kraeuter, J. N. and Castagna, M., Developments in aquaculture and fisheries science, 31, Elsevier, Amsterdam, 2001.

Hallock, P. and Schlager, W.: Nutrient excess and the demise of coral reefs and carbonate platforms, Palaios, 1, 389-398, 1986.

Helmle, K. P., Dodge, R. E., Swart, P. K., Gledhill, D. K., and Eakin, C. M.: Growth rates of Florida corals from 1937 to
1996 and their response to climate change, Nat. Commun., 2, 6, doi:10.1038/ncomms1222, 2011.

Helmle, K. P., Kohler, K. E., and Dodge, R. E.: The coral Xradiograph densitometry system: CoralXDS, Nova Southeastern University, Fort-Lauderdale-Davie, 2002.

Highsmith, R. C.: Coral growth rates and environmental control of density banding, J. Exp. Mar. Biol. Ecol., 37, 105-125, 1979.

Highsmith, R. C., Lueptow, R. L., and Schonberg, S. C.: Growth and bioerosion of three massive corals on the Belize barrier reef, Mar. Ecol.-Prog. Ser., 13, 261-271, 1983.

Hofmann, G. E., Smith, J. E., Johnson, K. S., Send, U., Levin, L. A., Micheli, F., Paytan, A., Price, N. N., Peterson, B., Takeshita, Y., Matson, P. G., Derse Crook, E., Kroeker, K. J., Gambi, M. C., Rivest, E. B., Frieder, C. A., Yu, P. C., and Martz, T. R.: HighFrequency Dynamics of Ocean $\mathrm{pH}$ : A Multi-Ecosystem Comparison, PLoS ONE, 6, doi:10.1371/journal.pone.0028983, 2011.

Hönisch, B., Ridgwell, A., Schmidt, D. N., Thomas, E., Gibbs, S. J., Slujis, A., Zeebe, R., Kump, L., Martindale, R. C., Greene, S. E., Kiessling, W., Ries, J., Zachos, J. C., Royer, D. L., Barker, S., Marchitto, T. M., Moyer, R., Pelejero, C., Ziveri, P., Foster, G. L., and Williams, B.: The geological record of ocean acidification, Science, 335, 1058-1063, 2012.

Hudson, J. H., Powell, G. V. N., Robblee, M. B., and Smith III, T. J.: A 107-year-old coral from Florida Bay: barometer of natural and man-induced catastrophies?, B. Mar. Sci., 44, 283-291, 1989.

IPCC: Summary for Policymakers, in: Climate Change 2013: The Physical Science Basis. Contribution of Working Group I to the Fifth Assessment Report of the Intergovernmental Panel on Climate Change, edited by: Stocker, T., Qin, D., Plattner, G.-K., Tignor, M. M. B., Allen, S. K., Boschung, J., Nauels, A., Xia, Y., Bex, V., and Midgley, P. M., Cambridge University Press, Cambridge, United Kingdom and New York, NY, USA, 2013.

Johnson, K. G. and Pérez, M. E.: Skeletal extension rates of Cenozoic Caribbean reef corals, Palaios, 21, 262-271, 2006.

Jones, D. S. and Allmon, W. D.: Records of upwelling, seasonality and growth in stable-isotope profiles of Pliocene mollusk shells from Florida, Lethaia, 28, 61-74, 1995.

Kiessling, W., Simpson, C., Beck, B., Mewis, H., and Pandolfi, J. M.: Equatorial decline of reef corals during the last Pleistocene interglacial, P. Natl. Acad. Sci. USA, 109, 21378-21383, 2012.

Klein, R., Pätzold, J., Wefer, G., and Loya, Y.: Depth-related timing of density band formation in Porites spp. corals from the Red Sea inferred from X-ray chronology and stable isotope composition, Mar. Ecol.-Prog. Ser., 97, 99-104, 1993.

Knutson, D. W., Buddemeier, R. W., and Smith, S. V.: Coral chronometers: seasonal growth bands in reef corals, Science, 177, 270-272, 1972.

Kuffner, I. B., Hickey, T. D., and Morrison, J. M.: Calcification rate of the massive coral Siderastrea sidera and crustose coralline algae along the Florida Keys (USA) outer-reef tract, Coral Reefs, 32, 987-997, 2013.

Langdon, C., Takahashi, T., Sweeney, C., Chipman, D., and Goddard, J.: Effect of calcium carbonate saturation on the calcification rate of an experimental coral reef, Global Biogeochem. Cy., 14, 639-654, 2000.

Leder, J. J., Swart, P. K., Szmant, A., and Dodge, R. E.: The origin of variations in the isotopic record of scleractinian corals: 1 . Oxygen, Geochim. Cosmochim. Ac., 60, 2857-2870, 1996. 
Lidz, B. H.: Florida Keys, in: Encyclopedia of modern coral reefs - structure, form and process, edited by: Hopley, D., Springer, Dordrecht, 2011.

Lloyd, R. M.: A palaeoecological interpretation of the Caloosahatchee Formation, using stable isotope methods, J. Geol., 77, $1-25,1969$

Logan, A. and Tomascik, T.: Extension growth rates in two coral species from high-latitude reefs of Bermuda, Coral Reefs, 10, 155-160, 1991.

Lough, J. M.: Coral calcification from skeletal records revisited, Mar. Ecol.-Prog. Ser., 373, 257-264, 2008.

Lough, J. M. and Barnes, D. J.: Environmental controls on growth of the massive coral Porites, J. Exp. Mar. Biol. Ecol., 245, 225243, 2000 .

Lough, J. M. and Cooper, T. F.: New insights from coral growth band studies in an era of rapid environmental change, Earth-Sci. Rev., 108, 170-184, 2011.

Macintyre, I. G. and Pilkey, O. H.: Tropical Reef Corals: Tolerance of Low Temperatures on the North Carolina shelf, Science, 166, 374-375, 1969

Mallela, J. and Perry, C. T.: Calcium carbonate budgets for two coral reefs affected by different terrestrial runoff regimes, Rio Bueno, Jamaica, Coral Reefs, 26, 129-145, 2007.

Manzello, D. P., Enochs, I. C., Bruckner, A., Renaud, P. G., Kolodziej, G., Budd, D. A., Carlton, R., and Glynn, P. W.: Galapagos coral reef persistence after ENSO warming across an acidification gradient, Geophys. Res. Lett., 41, 9001-9008, 2014.

Manzello, D. P., Enochs, I. C., Kolodziej, G., and Carlton, R.: Coral growth patterns of Montastraea cavernosa and Porites astreoides in the Florida Keys: The importance of thermal stress and inimical waters, J. Exp. Mar. Biol. Ecol., 471, 198-207, 2015a.

Manzello, D. P., Enochs, I. C., Kolodziej, G., and Carlton, R.: Recent decade of growth and calcification of Orbicella falveolata in the Florida Keys: an inshore-offshore comparison, Mar. Ecol.Prog. Ser., 521, 81-89, 2015 b.

McCulloch, M., Fallon, S., Wyndham, T., Hendy, E., Lough, J., and Barnes, D.: Coral record of increased sediment flux to the inner Great Barrier Reef since European settlement, Nature, 421, 727730, 2003

McGregor, H. V. and Gagan, M. K.: Diagenesis and geochemistry of Porites corals from Papua New Guinea: Implications for paleoclimate reconstruction, Geochim. Cosmochim. Ac., 67, 21472156, 2003.

Meeder, J. F.: A field guide with road log to "The Pliocene fossil reef of southwest Florida", Miami, 19, 1979.

Mertz-Kraus, R.: Mediterranean-type climate in the south Aegean (Eastern Mediterranean) during the Late Miocene: Evidence from isotope and element proxies, Dr. rer. nat. Dissertation, Fachbereich Chemie, Pharmazie und Geowissenschaften, Universität Mainz, Mainz, 129 pp., 2009.

Mertz-Kraus, R., Brachert, T. C., Jochum, K. P., Reuter, M., and Stoll, B.: LA-ICP-MS analyses on coral growth increments reveal heavy winter rain in the Eastern Mediterranean at $9 \mathrm{Ma}$, Palaeogeogr. Palaeocl., 273, 25-40, 2009a.

Mertz-Kraus, R., Brachert, T. C., and Reuter, M.: Tarbellastraea (Scleractinia): A new stable isotope archive for Late Miocene paleoenvironments in the Mediterranean, Palaeogeogr. Palaeocl., 257, 294-307, 2008
Mertz-Kraus, R., Brachert, T. C., Reuter, M., Galer, S. J. G., Fassoulas, C., and Iliopoulos, G.: Late Miocene sea surface salinity variability in the Eastern Mediterranean inferred from coral aragonite $\delta^{18} \mathrm{O}$ (Crete, Greece), Chem. Geol., 262, 202-216, $2009 \mathrm{~b}$.

Miller, K. G., Wright, J. D., Browning, J. V., Kulpecz, A., Kominz, M., Naish, T. R., Cramer, B. S., Rosenthal, Y., Peltier, W. R., and Sosdian, S.: High tide of the warm Pliocene: Implications of global sea level for Antarctic deglaciation, Geology, 40, 407410, doi:10.1130/G32869.1, 2012.

Nothdurft, L. D. and Webb, G. E.: Earliest diagenesis in scleractinian coral skeletons: implications for palaeoclimate-sensitive geochemical archives, Facies, 55, 161-201, 2009.

O’Brien, C. L., Foster, G. L., Martinez-Boti, M. A., Abell, R., Rae, J. W. B., and Pancost, R. D.: High sea surface temperatures in tropical warm pools during the Pliocene, Nat. Geosci., 7, 606611, 2014.

Okazaki, R. R., Swart, P. K., and Langdon, C.: Stress-tolerant corals of Florida Bay are vulnerable to ocean acidification, Coral Reefs, 32, 671-683, doi:10.1007/s00338-013-1015-3, 2013.

Perrin, C.: Diagenèse précoce des biocristaux carbonatés : transformations isominérales de l'aragonite corallienne, Bulletin de la Société Géologique de France, 175, 95-106, 2004.

Petit, J. R., Jouzel, J., Raynaud, D., Barkov, N. I., Barnola, J.-M., Basile, I., Bender, M., Chappellaz, J., Davis, M., Delaygue, G., Delmotte, M., Kotlyakov, V. M., Legrand, M., Lipenkov, V. Y., Lorius, C., Pépin, L., Ritz, C., Saltzman, E., and Stievenard, M.: Climate and atmospheric history of the past 420000 years from the Vostok ice core, Antarctica, Nature, 399, 429-436, 1999.

Petuch, E. J. and Roberts, C. E.: The geology of the Everglades and adjacent areas, CRC Press, New York and Boca Raton, 2007.

Pratchett, M. S., Anderson, K. D., Hoogenboom, M. O., Widman, E., Baird, A. H., Pandolfi, J. M., Edmunds, P. J., and Lough, J. M.: Spatia, temporal and taxonomic variation in coral growth implications for the structure and function of coral reef ecosystems, Oceanogr. Mar. Biol., 53, 215-295, 2015.

Reuter, M., Brachert, T. C., and Kroeger, K. F.: Diagenesis of growth bands in fossil scleractinian corals: Identification and modes of preservation, Facies, 51, 155-168, 2005.

Riding, R., Liang, L., and Braga, J.-C.: Millennial-scale ocean acidification and late Quaternary decline of cryptic bacterial crusts in tropical reefs, Geobiology, 12, 387-405, doi:10.1111/gbi.12097, 2014.

Riegl, B. and Piller, W. E.: Possible refugia for reefs in times of environmental stress, Int. J. Earth Sci., 92, 520-531, 2003.

Roulier, L. M. and Quinn, T. M.: Seasonal- to decadal-scale climatic variability in southwest Florida during the middle Pliocene: Inferences from a coralline stable isotope record, Paleoceanography, 10, 429-443, 1995.

Schroeder, J. H. and Purser, B. H. (Eds.): Reef Diagenesis, SpringerVerlag, New York, 1986.

Seki, O., Foster, G. L., Schmidt, D. N., Mackensen, A., Kawamura, K., and Pancost, R. D.: Alkenone and boron-based Pliocene $p \mathrm{CO}_{2}$ records, Earth Planet. Sc. Lett., 292, 201-211, 2010.

Shen, G. T. and Dunbar, R. B.: Environmental controls on uranium in reef corals, Geochim. Cosmochim. Ac., 59, 2009-2024, 1995.

Shinn, E. A.: Coral growth-rate, an environmental indicator, J. Paleontol., 40, 233-240, 1966. 
Sinclair, D. J., Kinsley, L. P. J., and McCulloch, M. T.: High resolution analysis of trace elements in corals by laser ablation ICPMS, Geochim. Cosmochim. Ac., 62, 1889-1901, 1998.

Swart, P. K.: Carbon and oxygen isotope fractionation in scleractinian corals: A review, Earth-Sci. Rev., 19, 51-80, 1983.

Swart, P. K.: The strontium, magnesium and sodium composition of recent scleractinian coral skeletons as standards for palaeoenvironmental analysis, Palaeogeogr. Palaeocl., 34, 115-136, 1981.

Swart, P. K., Greer, L., Rosenheim, B. E., Moses, C. S., Waite, A. J., Winter, A., Dodge, R. E., and Helmle, K.: The ${ }^{13}$ C Suess effect in scleractinian corals mirror changes in the anthropogenic $\mathrm{CO}_{2}$ inventory of the surface oceans, Geophys. Res. Lett., 37, L05604, doi:10.1029/2009g1041397, 2010.

Swart, P. K., Healy, G., Greer, L., Lutz, M., Saied, A., Anderegg, D., Dodge, R. E., and Rudnick, D.: The use of proxy chemical records in coral skeletons to ascertain past environmental conditions in Florida Bay, Estuarines, 22, 384-397, 1999.

Swart, P. K., Healy, G. F., Dodge, R. E., Kramer, P., Hudson, J. H., Halley, R. B., and Robblee, M. B.: The stable oxygen and carbon isotopic record from a coral growing in Florida Bay: a 160 year record of climatic and anthropogenic influence, Palaeogeogr. Palaeocl., 123, 219-237, 1996.
Tanzil, J. T. I., Brown, B. E., Tudhope, A. W., and Dunne, R. P.: Decline in skeletal growth of the coral Porites lutea from the Andaman Sea, South Thailand between 1984 and 2005, Coral Reefs, 28, 519-528, doi:10.1007/s00338-008-0457-5, 2009.

Tao, K. and Grossman, E. L.: Origin of high productivity in the Pliocene of the Florida platform: Evidence from stable isotopes, Palaios, 25, 796-806, 2010.

Townsend, C. R., Begon, M., and Harper, J. L.: Essentials of Ecology, Blackwell, Oxford, 2008.

Worum, F. P., Carricart-Ganivet, J. P., Besnon, L., and Golicher, D.: Simulation and observation of annual density banding in skeletons of Montastrea (Cnidaria: Scleractinia) growing under thermal stress associated with ocean warming, Limnol. Oceanogr., 52, 2317-2323, 2007. 